\title{
Ecological insights into soil health according to the life-history traits and environment-wide associations of bacteria in agricultural soils
}

Roland C. Wilhelm, Joseph P. Amsili, Kirsten S.M. Kurtz, Harold M. van Es and Daniel H. Buckley*

School of Integrative Plant Sciences, Bradfield Hall, Cornell University, Ithaca, NY, 14853, USA

*Corresponding Author:

Current address:
Dr. Daniel Buckley

School of Integrative Plant Science, 306 Tower Road,

Cornell University, Ithaca, NY 14853

Telephone: +1 (607) 255-1716

E-mail: dbuckley@,cornell.edu

Running Title: "Microbiome-based insights into soil health"

Keywords: soil health, microbial ecology, life-history strategies, environment-wide associations, agricultural soil. 


\begin{abstract}
1 Soil health assessment may be enhanced by monitoring changes in bacterial populations that are 2 indicators of various biological, physical, and chemical properties of soil. However, the lack of 3 ecological information for many abundant bacteria in agricultural soils limits our understanding of 4 indicator responses and, thus, their utility for guiding management. We identified bacterial 5 indicators of twelve conventional measures of soil health, and tillage intensity, from a 16S rRNA 6 gene-based survey of farmland across North America. We then analyzed trends according to 7 bacterial life-history frameworks and an environment-wide association survey (EWAS) to gain 8 ecological insights. Life-history traits were assessed using genomic traits inferred from taxonomic 9 classifications and included: genome size, $r r n$ copy number, and coding density. An EWAS was 10 conducted using 89 studies of agricultural land management. Most bacterial indicators were 11 positively correlated with biological measures and negatively correlated with physical and 12 chemical measures of soil health, revealing broad differences in the way management shapes 13 bacterial associations with soil health. High soil health ratings corresponded with life-history traits 14 associated with metabolic dependency (smaller genome and lower coding density), while lower 15 health scores corresponded with traits selected for by environmental instability and disturbance 16 (larger genome and multiple $r r n$ ). Trade-offs in community-weighted genome size explained most 17 variation in overall health score. EWAS confirmed the importance of disturbance-adapted bacterial 18 indicators, underscoring the impacts of tillage on soil bacterial communities. These findings 19 provide insights into the ecological relationships between bacterial indicators and soil health and 20 illustrate new approaches for interpreting patterns in microbiome data.
\end{abstract}




\section{Introduction}

Managing soil health promotes the long-term fertility and ecological integrity of

22 agricultural lands $[1,2]$. Soil health encompasses a range of soil properties that contribute value to

23 agroecosystems, including nutrient and water cycling, biodiversity, plant pathogen suppression,

24 and pollution mitigation. Soil health is monitored using biological, physical, and chemical

25 indicators that correspond with these functions [3-5]. Ideally, indicators should be interpretable

26 and exhibit a dynamic response to management practices [6-9]. The soil microbiome has

27 considerable potential to serve in this capacity. Microbial communities are highly sensitive to

28 management practices [10-13], including those that shape soil health in agricultural systems [14-

29 18]. The broad ecological and functional diversity of bacteria in soil provides rich information

30 about soil conditions, which was recently used to predict soil health status [19]. However, our

31 ability to interpret the responses of bacterial indicators is limited by our sparse understanding of

32 the ecology and function of most bacteria in soil. Developing ways to bridge this gap will expand

33 the utility of microbiome data in soil health monitoring.

Life-history frameworks offer a way to derive ecological information from trends in the

35 soil bacterial communities and have provided insight into processes like carbon and nitrogen

36 cycling [20-23]. The life-history strategies of every organism are shaped by tradeoffs between

37 growth, survival, and reproduction, and can manifest in diverse physiological traits related to

38 growth rate, stress tolerance, dormancy, dispersal, and resource acquisition. Life-history

39 frameworks group organisms with similar life-history strategies into ecological categories to help

40 interpret broad changes in microbiome structure and function. The copiotroph-oligotroph spectrum

41 was one of the first life-history frameworks applied to the soil microbiome, grouping organisms

42 by adaptations to high versus low resource niches with a focus on traits related to growth rate [24].

43 Other life-history frameworks focus on tradeoffs in the metabolic breadth between generalists and 
44 specialists [25], or a tripartite relationship between adaptations for yield, competition, and stress

45 tolerance $[23,26,27]$, or the metabolic dependency of organisms ranging from more independent

46 ('prototrophic') to more dependent ('auxotrophic') [28]. Life-history strategies can be identified

47 from their influences on the evolution of bacterial genomes and can be inferred from microbiome

48 amplicon sequencing data based on phylogenetic relatedness to genomes available in public

49 databases [29-32]. Life-history frameworks have been used to interpret changes in bacterial

50 communities in relation to natural processes and management practices that affect soil health, such

51 as aggregate formation [17] and cover crop and tillage practices [29, 33], respectively.

52 While promising, life-history frameworks remain untested in their capacity to represent the

53 breadth of trait diversity of soil bacteria. Furthermore, many of the most active and abundant

54 microorganisms in agricultural soils lack representative genomes, from which traits might be

55 predicted, and are known exclusively by their phylogenetic gene markers [34-37]. Ecological

56 information can still be derived for these organisms by profiling their phylogenetic gene markers

57 across the growing number of publicly available sequencing projects [38, 39]. An 'environment-

58 wide association survey' (EWAS) approach follows the principle of reverse ecology, where

59 ecological attributes are inferred from the changes in abundance and distribution of a gene or

60 genome across habitat, niche, or experiment [40]. Traditional approaches assign a trait using

61 curated databases [41, 42], which exclude uncultured or poorly characterized taxa. This is

62 problematic as these unclassified taxa are commonly indicative of properties relevant to soil health

$63[19,37,43,44]$. In contrast, EWAS requires no prior knowledge, with information gained for any

64 organism represented in sequencing databases [45-48]. An EWAS approach is primarily limited

65 by the poor quality of metadata reported for most sequencing projects [49] and a historical lack of

66 standardization in sequencing workflows. These drawbacks are partially compensated for by the 
67 sheer volume of available sequencing projects. Renewed efforts to systematize data publishing

68 will improve the efficacy of EWAS over time [50].

This study identifies and seeks to explain the relationships between bacterial indicators of

70 twelve conventional measures of soil health using a large survey of farmland from across North

71 America. Our first objective was to identify the bacterial indicators of biological, physical, and

72 chemical measures of soil health, as well as tillage practice, using 16S rRNA gene amplicon

73 sequencing data. Our second objective was to evaluate trends in bacterial indicators using life-

74 history frameworks and an EWAS to better understand the ecological basis for their associations

75 with soil health. We tested whether trends in community-weighted genomic traits, corresponding

76 to life-history frameworks, matched underlying assumptions about soil health (Table 1). Next, we

77 obtained the environment-wide associations of bacterial indicators in a survey of 89 studies of

78 agricultural soils and tested whether associations, grouped by study factors into broad (disturbance,

79 management, and rhizosphere association) and specific associations (fertilization, land-use, tillage,

80 drought etc.) were correlated with soil health. These approaches provided ecological information

81 about the bacterial indicators of soil health, affording new perspectives on soil health management.

\section{Methods}

82 Bacterial community and soil health data collection

83 Our primary dataset consisted of 778 soil samples sourced from farmland across the USA

84 as part of an initiative by Cornell University and the USDA Natural Resources Conservation

85 Service to characterize soil health. This dataset was used in a separate study to test the accuracy of

86 microbiome-based machine learning for predicting soil health [19]. Our study aims to identify

87 indicators and explore their underlying ecological basis for their association with soil health, which

88 have yet to be examined. 
$90=2$ sample per group, $\mathrm{n}_{\text {mean }}=5, \mathrm{n}_{\max }=48$ ). Soil health data was collected for each sample using

91 the Comprehensive Assessment of Soil Health (CASH) framework (Table S1), which uses

92 biological (soil organic matter, respiration, ACE protein, and active carbon, also known as

93 'permanganate oxidizable organic carbon'), chemical ( $\mathrm{pH}$, phosphorus, potassium, and minor

94 elements), and physical ratings of soil health (aggregate stability, available water capacity, soil

95 texture, and surface and subsurface hardness) [7]. Data on tillage was collected for most soils $(\mathrm{n}=$

96 599) and was coded as 'till' versus 'no till.' Higher surface and subsurface hardness ratings were

97 inverted so that more compacted soils corresponded with higher ratings (opposite of CASH); these

98 ratings present for a subset of samples ( $n=309$ and 292, respectively). Measurements for each soil

99 property were transformed using a scoring function [7] to create a normalized rating that accounts

100 for differences in soil texture. A total health score was then calculated from the unweighted mean

101 of all twelve ratings.

102

Total DNA was extracted from soils to determine bacterial community structure and as a

103 measure of microbial biomass [51]. DNA was extracted using the DNeasy PowerSoil Kit, as per

104 manufacturers recommendation (QIAGEN, Germantown, MD, USA). DNA concentration was

105 quantified using the Quant-iT ${ }^{\mathrm{TM}}$ PicoGreen ${ }^{\mathrm{TM}}$ dsDNA Assay Kit (Thermo Fisher Scientific, Inc.,

106 Waltham, MA, USA). Bacterial community composition was determined through amplicon

107 sequencing of the V4 region of the 16S rRNA gene using Illumina MiSeq (2x250 paired-end) and

108 dual-indexed barcoded primers (515f/806r) as previously described [19]. Operational taxonomic

109 units (OTUs) were defined as amplicon sequence variants and assigned taxonomic classifications

110 using QIIME2 (v. 2020.2) [52] with dependencies on DADA2 [38] and the Silva database (nr_v132) 
111 [53], respectively. Raw sequencing data was archived at the National Centre for Biotechnology

112 Information (BioProject: PRJEB35975).

113 Identifying bacterial indicators of soil health

114 Bacterial OTUs indicative of soil health were determined by Spearman rank correlations

115 using the 'rcorr' function in the R package Hmisc (v. 1.34.0) [54]. Prior to correlation analyses,

116 data was sparsity-filtered and normalized by sequencing library depth and reported as counts per

117 thousand reads as previously described [19]. P-values were adjusted according to the Benjamini

118 and Hochberg false discovery rate [55]. Weak correlations $\left(\mathrm{r}<|0.3|\right.$ and $\left.p_{\text {adj }}>0.05\right)$ were removed

119 [56]. Indicator species analyses was used to identify indicators for tillage intensity using the

120 "multipatt" function in the R package indicspecies [57]. All analyses can be reproduced with

121 scripts included in the Supplementary Data package.

122 Community-weighted genomic traits and life-history framework analyses

123 OTUs were assigned trait values corresponding to genomic traits associated with life-

124 history frameworks (Table 1). The genomic traits included: genome size and coding density (total

125 length of coding regions / genome size) and the average abundance of $r r n$ operons, CRISPR arrays

126 and biosynthetic gene clusters per genome. Genome data was downloaded from the IMG-ER

127 (downloaded March $\left.15^{\text {th }}, 2020\right)$ [58] and was comprised of data from isolate $(n=68,600)$, single-

128 cell amplified $(n=3,400)$ and metagenome-assembled genomes $(n=8,800)$. Gene abundances

129 were first normalized by genome size. OTUs were assigned a trait value iteratively based on

130 taxonomic classification. Unclassified OTUs at the rank genus were progressively matched to

131 averaged trait values at higher taxonomic ranks. Most OTUs were assigned a trait value (20,148 /

$13221,463 ; 94 \%)$ and the majority were assigned at their lowest classified taxonomic rank (58\%). The

133 community-weighted average trait values were calculated for whole bacterial communities using

134 the weighted mean based on the relative abundance of each OTU in the community. Additionally, 
135 community-weighted $r r n$ abundance was re-calculated using output from the $r r n \mathrm{DB}$ (v. 5.6) [59],

136 yielding results consistent with calculations derived from IMG-ER data.

137 Environment-wide Association Survey

138 We compiled 89 studies from agricultural or related terrestrial environments, totaling

13914,780 individual 16S rRNA gene amplicon libraries, termed the 'AgroEcoDB.' Amplicon

140 libraries associated with NCBI BioProjects with taxonomic IDs for "soil metagenome" (taxID:

141 410658), “compost metagenome" (702656), “decomposition metagenome" (1897463), "fertilizer

142 metagenome" (1765030), “manure metagenome" (1792145), "rhizosphere metagenome"

143 (939928), and "wood decay metagenome" (1593443) were downloaded on May 15", 2020. The

144 final database was filtered from an initial 729 BioProjects to 89 based on the following criteria: (i)

145 common overlap of the V4 region of the 16S rRNA gene, (ii) experimental manipulations, when

146 used, were typical of agricultural management, and (iii) contained at least 15 samples with well-

147 curated metadata (details in Supplementary Methods). Study factors were categorized by

148 management categories (e.g., inorganic versus organic fertilizer and other broad strategies, like

149 crop rotation), disturbance (tillage, drought etc.), plant association (bulk vs. rhizosphere soil),

150 biome (grassland vs. cropland) and other minor categories (decomposition, soil depth etc.) (Table

$151 \mathrm{~S} 2$ ). Indicator species analyses was used to attribute an indicator value to OTUs in the AgroEcoDB

152 based on each individual study factor. Study factors were coded to reflect expectations about their

153 relationship with soil health and indicator values were scored as positive or negative based on

154 whether the relationship was positively (reduced tillage, OM management, etc.) or negatively

155 associated with soil health (Table S2). Our subsequent analyses were a test of whether these

156 assumptions were supported by trends in soil health data. 
Bioinformatic Analyses

Statistics were performed using R (v. 4.0.3) [60] with dependency on the following packages: reshape2 (v. 1.4.4), ggplot2 (v. 3.3.2), plyr (v. 1.8.6) [61-63], and phyloseq (v. 1.34.0)

160 [64]. Observed species richness and Shannon diversity estimates were averaged from the

161 'plot_richness' function based on 200 permutations of rarefied counts ( $\mathrm{n}=1,000$ reads).

162 Permutational multivariate analysis of variance (PERMANOVA) was performed on Bray-Curtis

163 dissimilarity using the R package vegan (v. 2.5.7) [73] with 999 permutations. PERMANOVA was

164 repeated with 50 permutations of factor order to obtain average $\mathrm{R}^{2}$ values. The relative importance

165 of community-weighted traits and environment-wide associations for explaining variation in

166 community composition was compared with relaimpo [65]. Co-occurrence networks were

167 constructed for bacterial taxa (aggregated by genus) based on whether two genera shared a

168 common indicator status for each of the twelve soil health ratings. Edges were weighted by the

169 number of OTUs co-occurring between nodes (i.e., each genus). Indicators with negative and

170 positive correlations with ratings were visualized in separate networks using Gephi (v.0.9.2) [66]

171 with network topography determined by the Yifan $\mathrm{Hu}$ 'proportional' force-directed graphing

172 algorithm (relative strength $=2$ ) [67].

\section{Results}

173 Relationships among measures of soil health

174 Biological ratings were highly interrelated and positively correlated with total health score

175 and with aggregate stability, a physical property influenced by biological activity (Figure 1; full

176 matrix in Figure S1). Total health score was negatively correlated with surface and subsurface

177 hardness ratings (where a higher rating indicates greater compaction), tillage intensity, and sand

178 content. DNA yield was significantly positively correlated with soil health $(\mathrm{r}=0.51 ; p<0.001)$,

179 but was influenced by clay content, likely as a result of higher sorption reducing DNA extraction 
180 efficiency (Figure S2). Bacterial indicators of soil health ratings were apparent despite broad

181 variation in community structure due to geography (PERMANOVA; $\mathrm{R}^{2}=0.58$ ), followed by

182 tillage intensity (0.02), soil texture class $(0.009), \mathrm{pH}(0.008)$ and total health score $(0.006$; Table

$183 \mathrm{~S} 3)$.

Bacterial indicators of soil health

OTUs were correlated with each of the twelve health ratings and total health score to identify bacterial indicators $\left(\mathrm{r}>|0.3|\right.$ and $\left.p_{\text {adj }}<0.05\right)$. A subset of OTUs $(1,874 / 21,463)$ were

were taxonomically diverse (348 different classifications at rank genus) with most belonging to compared to the overall dataset (430 / 943). Positively correlated OTUs were primarily indicative

192 of biological ratings, while negatively correlated OTUs were indicative of physical or chemical

193 ratings (Figure 2). Many genera (46\%) contained a mix of indicator OTUs responding either 194 positively or negatively to different health ratings. However, the majority of indicator OTUs were 195 correlated in a consistent direction with one or more health ratings $(96 \% ; 1,798 / 1,874)$.

197 (Chloroflexi), Candidatus Udaeobacter (Verrucomicrobia), unclassified Xanthobacteraceae 198 (Alphaproteobacteria) and unclassified MB-A2-108 and Illumatobacteraceae (Actinobacteria; 199 full list in Table S4). The most consistent indicators of poorer physical, chemical and total health 200 score were classified as JG30-KF-CM45 (Chloroflexia), Ca. Nitrososphaeraceae (Archaea; 201 Thaumarchaeota), Sphingomonas (Alphaproteobacteria), and RB41 (Acidobacteria; 202 Pyrinomonadaceae). Many taxa occurring at high relative abundances (1-5\% of total read counts) 
204 in tilled fields $\left(\mathrm{n}_{\mathrm{OTU}}=292\right)$ in contrast to no till systems $\left(\mathrm{n}_{\mathrm{OTU}}=18\right)$. The predominant indicators

205 of tilled soils were members of Alphaproteobacteria (Sphingomonadaceae, Rhizobiaceae and

206 Caulobacteraceae), Pyrinomonadaceae, Chthoniobacter (Verrucomicrobia) and Terrabacter

207 (Actinobacteria). The main indicators of untilled fields were the aforementioned indicators of high

208 biological health ratings, as well as Gaiella (Actino.) and unclassified Solirubrobacterales

209 (Actino.).

210 Life-history frameworks

211 We evaluated trends in the community-weighted averages of genomic traits represented in

212 several life-history frameworks (Table 1). Communities with a higher prevalence of bacteria with

213 larger genomes and those which encoded more biosynthetic gene clusters (BGCs) were associated

214 with lower total health score (Figure 3A), traits which correspond with more competitive,

215 independent taxa. Communities with a higher prevalence of bacteria with high coding density were

216 associated with higher health score, a trait associated with more dependent taxa. The relationships

217 among traits in community-weighted data partially reflected the existing relationships observed in

218 genomic data (Mantel statistic $\mathrm{r}=0.64 ; p=0.01$ ). However, the relationships among genome size,

219 BGCs, and $r r n$ copies differed from these existing relationship in community-weighted data

220 (Figure 3B).

Community-weighted $r r n$ copy number was not correlated with total health score $(\mathrm{r}=$

222 0.003). However, community-weighted $r r n$ copy number was significantly higher in tilled soils

223 (Wilcoxon, $p<0.001$; Figure 4) and exhibited significant correlations with soil surface and sub-

224 surface hardness rating (Figure 5A). The trends in community-weighted $r r n$ copy number were 225 driven by the increased relative abundances of Georgenia $\left(\overline{\mathrm{x}}_{r r n}=5.7\right.$; Actino. $)$, Bacillaceae $\left(\overline{\mathrm{x}}_{r r n}=\right.$ 226 5.5; Firmicutes), and Planococcaceae ( $\overline{\mathrm{x}}_{r r n}=5.4$; Firmicutes). Community-weighted genome size 227 and BGCs abundance were negatively correlated with total health score, and like $r r n$ copy number, 
showed increased prevalence in tilled soils (Figure 4). Genome size and BGCs were primarily correlated with biological ratings, unlike rrn copy number which was exclusively correlated with physical or chemical ratings (Figure 5A).

$\left.236 \overline{\mathrm{x}}_{\text {density }}=79.1\right)$. Community-weighted CRISPR array abundance exhibited some of the strongest

237 correlations with health ratings and was negatively correlated to water capacity, measures of OM 238 quality, and total health score (Figure 5A), and positively correlated with sand content $(\mathrm{r}=0.44 ; p$ $239<0.001)$

The majority of OTUs in the soil health dataset were present in the AgroEcoDB (notU $=$

24217,818 / 21,573), representing a total of $96.9 \%$ of sequences. A total of 8,760 overlapping OTUs

243 were identified as significant indicators $(p<0.01)$ of one or more study factors in the AgroEcoDB.

244 Indicator values for these OTUs were used to calculate community-weighted averages of broad

245 categories and sub-categories to assess general correlations between the environment-wide

246 associations of bacteria and soil health. Community-weighted environment-wide associations

247 explained more variation in bacterial community composition than community-weighted genomic

248 traits (Table 2A), primarily based on variation captured by associations with disturbance and 249 management strategy. However, community-weighted genome size explained the most variation 250 in total health score (Table 2B). Community-weighted environment-wide associations with 251 disturbance $(\mathrm{r}=0.12 ; p=0.001)$ and management $(\mathrm{r}=0.11 ; p=0.002)$ were positively correlated 
252 with total health score, demonstrating that our coding of study factors (i.e., indicators of health-

253 promoting factors were assigned a positive indicator value) generally conformed with expectations

254 about soil health.

255 The environment-wide associations of the most abundant bacterial indicators driving the

256 strong correlation between community-weighted genome size and active carbon were investigated

257 (Figure 5B). The bacterial indicators of active carbon with the largest estimated genomes were

258 classified as Chthoniobacter $\left(\overline{\mathrm{x}}_{\text {size }}=7.8 \mathrm{Mb} ; \overline{\mathrm{x}}_{\text {rel.abund. }}=0.5 \%\right.$ of total counts $)$,

259 Geodermatophilaceae (4.8 Mb; 1.0\%), and Sphingomonas (4.2 Mb; 1.7\%), and those with the

260 smallest were: Gaiella (1.5 Mb; 2.1\%), Ca. KD4-96 (2.3 Mb; 4.9\%), and Ca. Udaeobacter (2.7

$261 \mathrm{Mb} ; 3.5 \%)$. Of these representative taxa, those with larger genomes had consistently higher relative

262 abundances in tilled soils and those with low active carbon ratings, while the reverse was true for

263 those with smaller genomes (Figure S3). According to environment-wide associations, all

264 representative taxa were primarily associated with bulk soil rather than rhizosphere soil (Figure

265 6A). Their associations with soil disturbance were consistent, where taxa with larger genomes were

266 generally positively associated with disturbance (Figure 6B). These trends were driven by

267 disturbances related to tillage (Figure S4) and long-term irrigation regime (Figure S5). The

268 environment-wide associations with broader management strategies (crop rotation, land-use, and

269 fertilization) were variable (Figure 6C).

270 Active carbon is positively correlated with particulate forms of soil OM (POM), such as

271 cellulose and lignin [68, 69]. Therefore, we investigated whether the representative taxa had

272 preferences for soluble (DOM) versus particulate forms of POM in studies utilizing soil organic

273 matter amendments in the AgroEcoDB. Sphingomonas were indicators of POM amendment

274 (Indicvalue $=0.99, p=0.03$ ) in a study comparing xylose versus cellulose soil amendment [70], 
275 while no other representatives were indicators of either DOM or POM in studies comparing

276 amendments of cellobiose versus straw (PRJNA397131), nine substrates ranging in solubility

277 (PRJNA668741) or a wide variety of soluble and insoluble substrates (PRJNA594403).

278 Representative taxa were more impacted by tillage than by the retention of plant residues in a study

279 on soil management practices (Figure S4) [70], indicating responses to disturbance may play a

280 greater role than functions in OM decomposition.

\section{Discussion}

We sought ecological insights into the bacterial indicators of soil health by using life-

282 history frameworks and an EWAS. Our findings lend further evidence that the abundance patterns

283 of soil bacteria reflect changes in soil conditions relevant to soil health $[18,29]$ and, in our case,

284 at a spatial scale and with an operational dataset that suggest a broad utility in monitoring. A diverse

285 set of 348 unique bacterial genera were identified as indicators of one or more soil health rating,

286 yet the majority (62\%) were unclassified beyond the family level. This finding underscored the

287 need for alternative strategies, like life-history frameworks and EWAS, to extend beyond our

288 knowledge of cultivated bacteria to gain insights into bacterial indicators of soil health.

The effects of soil disturbance on soil health according to life-history traits

The relationship between community-weighted genome size and total health score was

291 among the strongest correlations observed for any genomic proxy for life-history traits (Figure 5)

292 and was the most important predictor of variation in total health score (Table 2B). On average,

293 communities with a greater proportion of bacteria with larger genomes occurred in soils with lower

294 health score, and lower biological ratings. This was contrary to our expectation that a large genome,

295 and the accompanied functional versatility, would provide competitors / generalists with an

296 advantage in soils characterized by a greater abundance and diversity of organic matter (i.e.,

297 healthier soils). The strong negative correlation between community-weighted genome size and 
active carbon (Figure 5B), suggested the trend may be driven by the relationship of indicators with

299 OM quality. However, the environment-wide associations of bacterial indicators of OM quality

300 explained less variation in total health score than genome size or tillage (Table 2B). Furthermore,

301 the main taxa driving trends in genome size did not exhibit associations with experimental

302 amendments of DOM or POM but, instead, were affected by disturbances like tillage (Figure S4)

303 and irrigation regimes (Figure S5).

304 Bacteria with larger genomes are more abundant in habitats characterized by high

305 environmental variability, where their expanded regulatory and metabolic capabilities provide

306 enhanced fitness [71, 72]. Thus, the larger community-weighted genome size associated with

307 lower soil health, and tillage, indicate a higher proportion of taxa adapted to environmental

308 instability, consistent with observations in tidal systems [73]. Conversely, bacteria with smaller

309 genomes, associated here with higher health, tend to be marked by dependencies on services

310 provided by microbial community members and may, therefore, be more sensitive to disruptions.

311 For example, Ca. Udeaobacter possess a remarkably reduced genome [74] and were among the

312 strongest indicators of high health rating and were most impacted by disturbances (Figure 6; Figure

313 S3; Figure S4). Along with a reduced genome size, Ca. Udeaobacter exhibit high levels of

314 auxotrophy and antibiotic tolerance $[74,75]$, characteristic of the life-history strategy of dependent

315 organisms, exemplified by members of Planctomyces $[28,76]$. Trade-offs in the putative capacity

316 to produce antibiotics were apparent in the positive correlation between community-weighted

317 BGC abundances and genome size. These observations suggest that life-history strategies marked

318 by independence (large genomes and higher BGC capacity) and dependence (small genome and

319 antibiotic tolerance) correspond with adaptations to environmental / community stability which

320 correlate with soil health. 
Our evidence suggests that community-weighted genome size may serve as an indication

322 of the effects of management on environmental complexity and stability, integrating the myriad

323 effect of disturbances from fertilization, tillage, watering, crop rotations, and harvesting. However,

324 we could not determine whether community trends were driven by the growth dynamics of

325 populations with larger or smaller genomes, or both, since sequencing data is a measure of relative

326 abundance [77]. Disentangling this dynamic is important for understanding the exact nature of the

327 relationship with genome size and, in future, may be addressed using internal standards [78-81].

While our analyses revealed patterns in the genomic traits and environment-wide associations of the soil microbiome, they also illustrated the challenges of categorizing the lifehistory strategies of bacteria into broad frameworks. For example, Chthoniobacter had a larger genome (ranging from 3.6 - 7.8 $\mathrm{Mb}$ ) and, like other taxa with larger genomes, were more prevalent in tilled soils (Figure S3). However, unlike taxa with larger genomes, Chthoniobacter were indicative of higher health ratings, similar to their close relative Ca. Udeaobacter (family

Chthoniobacteraceae) which have substantially smaller genomes $(2.7-3.2 \mathrm{Mb})$ and were less prevalent in tilled soils. Investigating the ecology of these abundant, closely related soil taxa may reveal differences in life-history strategies that illuminate more specific effects of soil management.

338 Bacterial indicators were primarily negatively correlated with physical and chemical

339 ratings in contrast to largely positive correlations with biological measures (Figure 2). These

340 overarching trends may correspond with differences in the nature of the management practices

341 driving the associations between bacterial populations and soil health. The primarily negative

342 correlations with physical and chemical properties may reflect the increased relative abundance of

343 stress tolerant taxa or taxa with metabolic functions associated with nutrient regimes experienced

344 at lower ends of the chemical and physical health spectrum (i.e., lithoautotrophic organisms or 
stress-tolerators). For example, the increased relative abundance of bacterial populations classified

to the family Nitrososphaeraceae were strongly indicative of soils with poorer soil health. Nitrososphaeraceae are ammonia-oxidizing archaea which are commonly enriched in

348 conventionally-managed agricultural soils fertilized with ammonia [18, 82] and exhibited

349 environment-wide associations with fertilizer use in the AgroEcoDB (Figure S6). Conversely, the

350 positive correlations with biological ratings may correspond with an increased relative abundance

351 of organoheterotrophs in soils with higher OM quantity and quality, consistent with the positive

352 correlations with respiration rating (activity) and DNA yield (biomass).

Community-weighted rrn copy number, a correlate of bacterial growth rate [83], was the

354 only trait that had a significant relationship with hardness ratings and the only trait not correlated

355 with total health score or biological ratings (Figure 4). Community-weighted rrn copy number was

356 significantly higher in tilled fields, matching our expectation that disturbance would favor fast-

357 growing copiotrophs, consistent with previous findings [84]. Notably, hardness ratings were

358 negatively correlated with rrn copy number, indicating communities in more compacted soils

359 tended to encode a higher number of $r r n$ operon. This matched our expectation that higher $r r n$

360 copy number would be associated with more degraded soils (Table 1), though the nature of the

361 relationship between fast-growing taxa and soil compaction is unclear. These results confirm the

362 influence of physical disturbance on bacterial life-history strategies related to growth rate and their

363 potential to serve as indicators of soil health.

Exploring relationships between coding density, CRISPR array abundance and soil health

As part of an exploratory analysis, we calculated community-weighted coding density as a

367 obligate forms of dependency apparent in epibionts, endobionts and parasites, resulting from the

368 relaxation of selection pressures and an accumulation of pseudogenes $[85,86]$. We expected lower 
community-weighted coding density may indicate higher trophic dependency, which we expected in more developed, healthier soils. The inverse relationship between community-weighted coding

371 density and DNA yield supported this expectation, showing that soils with more biomass tended

372 to have higher representation of putatively dependent taxa with lower coding density. OTUs

373 belonging to the family Gemmataceae $\left(\overline{\mathrm{x}}_{\text {rel.abund. }}=1.2 \%\right)$ were indicators of high DNA yield and

374 exhibited one of the lowest predicted coding density $\left(\overline{\mathrm{x}}_{\mathrm{c} . \mathrm{d}}=79.1\right)$. Prior evidence shows that

375 Gemmataceae are dependent on nutrient supplementation from hosts or community members [76].

376 However, contrary to expectations, overall community-weighted coding density was positively

377 correlated with total health score. The interpretation of this trend is complicated by our limited

378 understanding of the full scope of evolutionary forces shaping coding density.

We explored the relationship between community-weighted CRISPR array abundance and

soil health as a proxy for bacteriophage pressure. CRISPR array abundance was the only genomic

381 trait to exhibit strong inverse correlations with available water capacity and OM ratings, and to

382 have a positive correlation with sand content. These observations are consistent with the

383 observation that CRISPR provides greater fitness in low resource conditions relative to other phage

384 defense mechanisms [87]. However, our observations run counter to expectations that community-

385 weighted CRISPR array abundance would be greatest with wet, OM-rich soils, where phage

386 abundances are typically highest $[88,89]$. This relationship requires further study, especially since

387 CRISPR array abundance is a measure of the number of arrays, not the total length or number of 388 protospacers, which may better correlate with phage exposure [90].

\section{Conclusions}

Life-history frameworks and environment-wide association surveys provide new ways to

390 interpret and explore trends in microbiome data. Both approaches proved useful for studying

391 relationships between the soil microbiome and soil health, indicating their general utility in the 
392 study of other diverse and poorly characterized environmental microbiomes. Several community-

393 weighted genomic traits differed across the spectrum of soil health, and our EWAS provided a

394 means to test hypotheses about poorly described, but important, indicators of soil health. With

395 these methods, we found evidence that bacterial indicators of soil health largely corresponded to

396 disturbance-sensitive and stress-tolerant populations. Future research is needed to determine

397 whether disturbance-adapted bacteria not only reflect soil health but affect processes related to

398 healthier soils. Particular attention should be paid to their relationship with OM quantity and

399 quality, since a larger genome has been linked to lower carbon use efficiency [91]. As such, our

400 data suggests soil with a lower health status may be prone to carbon loss through respiration.

401 Overall, our study illustrates the value in considering the ecological attributes of bacterial

402 indicators of soil health to better understand and evaluate the effects of management practices.

\section{Acknowledgements}

We thank Christopher DeRito at Cornell University for his assistance in preparing

404 amplicon sequencing libraries. This work was supported by the USDA National Institute of Food 405 and Agriculture, Hatch project 1010520; by the U.S. Department of Energy, Office of Biological

406 \& Environmental Research Genomic Science Program under award number DE-SC0016364; and 407 by the USDA Natural Resource Conservation Service Conservation Innovation Grant, agreement 408 number: 69-3A75-16-039. Any opinions, findings, conclusions, or recommendations expressed in 409 this publication are those of the author(s) and do not necessarily reflect the view of the National 410 Institute of Food and Agriculture (NIFA), the United States Department of Agriculture (USDA), 411 or the United States Department of Energy. 


\section{Author Contributions}

RCW performed all data analysis, research, and writing. JPA, KSMK and HMV managed

413 sample collection and soil health testing. DHB guided all research efforts, including analyses and

414 writing.

\section{References}

415 1. Doran JW. Soil health and global sustainability: translating science into practice. Agric $416 \quad$ Ecosyst Environ 2002;88:119-127.

417 2. Wander MM, Cihacek LJ, Coyne M, Drijber RA, Grossman JM, et al. Developments 418 in Agricultural Soil Quality and Health: Reflections by the Research Committee on Soil 419 Organic Matter Management. Front Environ Sci 2019;7:1-9.

420 3. Stewart RD, Jian J, Gyawali AJ, Thomason WE, Badgley BD, et al. What we talk about when we talk about soil health. Agric Environ Lett 2018;3:5-9.

4. Rinot O, Levy GJ, Steinberger Y, Svoray T, Eshel G. Soil health assessment: A critical review of current methodologies and a proposed new approach. Sci Total Environ 2019;648:1484-1491.

5. Hurisso TT, Culman SW, Zhao K. Repeatability and spatiotemporal variability of emerging soil health indicators relative to routine soil nutrient tests. Soil Sci Soc Am J 2018;82:939-948.

6. Lilburne L, Sparling G, Schipper L. Soil quality monitoring in New Zealand: Development of an interpretative framework. Agric Ecosyst Environ 2004;104:535-544.

7. Moebius-Clune BN, Moebius-Clune DJ, Gugino BK, Idowu OJ, Schindelbeck RR, et al. Comprehensive assessment of soil health - the Cornell framework manual. 3rd ed. Ithaca, NY: Cornell University; 2017.

8. Fierer N, Wood SA, Bueno de Mesquita CP. How microbes can, and cannot, be used to assess soil health. Soil Biol Biochem 2021;153:108111.

9. Amsili JP, van Es HM, Schindelbeck RR. Cropping system and soil texture shape soil health outcomes and scoring functions. Soil Secur 2021;4:100012.

10. Simonin M, Voss KA, Hassett BA, Rocca JD, Wang SY, et al. In search of microbial indicator taxa: shifts in stream bacterial communities along an urbanization gradient. Environ Microbiol 2019;21:3653-3668.

11. Bissett A, Brown M V., Siciliano SD, Thrall PH. Microbial community responses to anthropogenically induced environmental change: Towards a systems approach. Ecol Lett 2013;16:128-139.

12. Wilhelm RC, Cardenas E, Maas KR, Leung H, McNeil L, et al. Biogeography and organic matter removal shape long-term effects of timber harvesting on forest soil microbial communities. ISME J 2017;11:2552-2568. 
14. Trivedi P, Delgado-Baquerizo M, Anderson IC, Singh BK. Response of soil properties and microbial communities to agriculture: Implications for primary productivity and soil health indicators. Front Plant Sci 2016;7:1-13.

15. Jiao S, Xu Y, Zhang J, Hao X. Core microbiota in agricultural soils and their potential associations with nutrient cycling. mSystems 2019;4:1-16.

16. Chang HX, Haudenshield JS, Bowen CR, Allen R, Iii W, et al. Metagenome-wide association study and machine learning prediction of bulk soil microbiome and crop productivity. Front Microbiol 2017;8:519.

17. Trivedi P, Delgado-Baquerizo M, Jeffries TC, Trivedi C, Anderson IC, et al. Soil aggregation and associated microbial communities modify the impact of agricultural management on carbon content. Environ Microbiol 2017;19:3070-3086.

18. Armbruster M, Goodall T, Hirsch PR, Ostle N, Puissant J, et al. Bacterial and archaeal J Soil Sci 2020;1-15.

19. Wilhelm RC, Es HM Van, Buckley DH. Predicting measures of soil health using the microbiome and supervised machine learning. Soil Biol Biochem 2022;164:108472.

20. Bouskill NJ, Tang J, Riley WJ, Brodie EL. Trait-based representation of biological nitrification: Model development, testing, and predicted community composition. Front Microbiol 2012;3:1-17.

21. Ho A, Kerckhof FM, Luke C, Reim A, Krause S, et al. Conceptualizing functional traits and ecological characteristics of methane-oxidizing bacteria as life strategies. Environ Microbiol Rep 2013;5:335-345.

22. Fierer N. Embracing the unknown: Disentangling the complexities of the soil microbiome. Nat Rev Microbiol 2017;15:579-590.

23. Malik AA, Martiny JBHH, Brodie EL, Martiny AC, Treseder KK, et al. Defining traitbased microbial strategies with consequences for soil carbon cycling under climate change. ISME J 2020;14:1-9.

24. Fierer N, Bradford MA, Jackson RB. Toward an ecological classification of soil bacteria. Ecology 2007;88:1354-1364.

25. Nunan N. The microbial habitat in soil: Scale, heterogeneity and functional consequences. J Plant Nutr Soil Sci 2017;180:425-429.

26. Grime JP. Evidence for the existence of three primary strategies in plants and its relevance for ecological and evolutionary theory. Am Nat 1977;111:1169-1194.

27. Barnett S, Youngblut ND, Koechli CN, Buckley DH. Life history strategies explain bacterial activity in the soil carbon cycle. bioRxiv. Epub ahead of print 2021. DOI: 10.1101/2021.03.19.436178.

28. Wilhelm RC, Pepe-Ranney C, Weisenhorn P, Lipton M, Buckley DH. Competitive exclusion and metabolic dependency among microorganisms structure the cellulose economy of an agricultural soil. MBio 2021;12:1-19.

29. Schmidt R, Gravuer K, Bossange A V., Mitchell J, Scow K. Long-term use of cover crops and no-till shift soil microbial community life strategies in agricultural soil. PLoS One 2018;13:1-19.

30. Pepe-Ranney C, Campbell AN, Koechli CN, Berthrong S, Buckley DH. Unearthing the 
492

493

494

495

496

497

498

499

500

501

502

503

504

505

506

507

508

509

510

511

512

513

514

515

516

ecology of soil microorganisms using a high resolution DNA-SIP approach to explore cellulose and xylose metabolism in soil. Front Microbiol 2016;7:1-17.

31. Gravuer K, Eskelinen A. Nutrient and rainfall additions shift phylogenetically estimated traits of soil microbial communities. Front Microbiol 2017;8:1-16.

32. Chen Y, Neilson JW, Kushwaha P, Maier RM, Barberán A. Life-history strategies of soil microbial communities in an arid ecosystem. ISME J. Epub ahead of print 2020. DOI: 10.1038/s41396-020-00803-y.

33. Degrune F, Theodorakopoulos N, Colinet G, Hiel MP, Hartmann M, et al. Temporal dynamics of soil microbial communities below the seedbed under two contrasting tillage regimes. Front Microbiol;8. Epub ahead of print 2017. DOI: 10.3389/fmicb.2017.01127.

34. Lupatini M, Korthals GW, de Hollander M, Janssens TKS, Kuramae EE. Soil microbiome is more heterogeneous in organic than in conventional farming system. Front Microbiol 2017;7:1-13.

35. Koechli C, Campbell AN, Pepe-ranney C, Buckley DH. Assessing fungal contributions to cellulose degradation in soil by using high- throughput stable isotope probing. Soil Biol Biochem 2019;130:150-158.

36. Furtak K, Grządziel J, Galązka A, Niedźwiecki J. Prevalence of unclassified bacteria in the soil bacterial community from floodplain meadows (fluvisols) under simulated flood conditions revealed by a metataxonomic approachss. Catena;188. Epub ahead of print 2020. DOI: $10.1016 /$ j.catena.2019.104448.

37. Schmidt R, Mitchell J, Scow K. Cover cropping and no-till increase diversity and symbiotroph:saprotroph ratios of soil fungal communities. Soil Biol Biochem 2019;129:99109.

38. Callahan BJ, McMurdie PJ, Rosen MJ, Han AW, Johnson AJA, et al. DADA2: Highresolution sample inference from Illumina amplicon data. Nat Methods 2016;13:581-583.

39. Callahan BJ, McMurdie PJ, Holmes SP. Exact sequence variants should replace operational taxonomic units in marker-gene data analysis. ISME J 2017;11:2639-2643.

40. Levy R, Borenstein E. Reverse Ecology : From systems to environments and back. 329345 .

41. Nguyen NH, Song Z, Bates ST, Branco S, Tedersoo L, et al. FUNGuild: An open annotation tool for parsing fungal community datasets by ecological guild. Fungal Ecol 2016;20:241-248.

42. Hamilton JP, Neeno-Eckwall EC, Adhikari BN, Perna NT, Tisserat N, et al. The Comprehensive Phytopathogen Genomics Resource: A web-based resource for data-mining plant pathogen genomes. Database 2011;1-13.

43. Detheridge AP, Brand G, Fychan R, Crotty F V., Sanderson R, et al. The legacy effect of cover crops on soil fungal populations in a cereal rotation. Agric Ecosyst Environ 2016;228:49-61.

44. McKenna TP, Crews TE, Kemp L, Sikes BA. Community structure of soil fungi in a novel perennial crop monoculture, annual agriculture, and native prairie reconstruction. PLoS One 2020;15:1-15.

45. Rocca JD, Simonin M, Blaszczak JR, Ernakovich JG, Gibbons SM, et al. The Microbiome Stress Project: Toward a global meta-analysis of environmental stressors and 
their effects on microbial communities. Front Microbiol 2019;9:3272.

46. Ramirez KS, Knight CG, De Hollander M, Brearley FQ, Constantinides B, et al. Detecting macroecological patterns in bacterial communities across independent studies of global soils. Nat Microbiol 2018;3:189-196.

47. Thompson LR, Sanders JG, McDonald D, Amir A, Ladau J, et al. A communal catalogue reveals Earth's multiscale microbial diversity. Nature 2017;551:457-463.

48. Lagkouvardos I, Joseph D, Kapfhammer M, Giritli S, Horn M, et al. IMNGS: A comprehensive open resource of processed 16S rRNA microbial profiles for ecology and diversity studies. Sci Rep 2016;6:1-9.

49. Jurburg SD, Konzack M, Eisenhauer N, Heintz-Buschart A. The archives are halfempty: a field-wide assessment of the availability of microbial community sequencing data Authors : bioRxiv 2020;1-18.

50. Emerson JB, Everhart SE, Eversole K, Frost KE, Herr JR, et al. Community-driven metadata standards for agricultural microbiome research. Phytobiomes J 2020;PBIOMES09-19-0.

51. Anderson TH, Martens R. DNA determinations during growth of soil microbial biomasses. Soil Biol Biochem 2013;57:487-495.

52. Bolyen E, Rideout JR, Dillon MR, Bokulich NA, Abnet CC, et al. Reproducible, interactive, scalable and extensible microbiome data science using QIIME 2. Nat Biotechnol 2019;37:852-857.

53. Quast C, Pruesse E, Yilmaz P, Gerken J, Schweer T, et al. The SILVA ribosomal RNA gene database project: Improved data processing and web-based tools. Nucleic Acids Res 2013;41:590-596.

54. Harrell F, Dupont C. Hmisc: Harrell miscellaneous. $R$ Packag.

55. Benjamini Y, Hochberg Y. Controlling the False Discovery Rate : A Practical and Powerful Approach to Multiple Testing. J R Stat Soc 1995;57:289-300.

56. Weiss S, Van Treuren W, Lozupone C, Faust K, Friedman J, et al. Correlation detection strategies in microbial data sets vary widely in sensitivity and precision. ISME $J$ 2016;10:1669-1681.

57. De Caceres M, Legendre P. Associations between species and groups of sites: indices and statistical inference. Ecology, URL http://sites.google.com/site/miqueldecaceres/. Ecology 2009;90:3566-3574.

58. Markowitz VM, Ivanova NN, Szeto E, Palaniappan K, Chu K, et al. IMG/M: A data management and analysis system for metagenomes. Nucleic Acids Res 2008;36:534-538.

59. Stoddard SF, Smith BJ, Hein R, Roller BRK, Schmidt M. rrnDB : improved tools for

60. Core Team R. R: a language and environment for statistical computing. $R$ Found Stat Comput.

574 61. Wickham H. Reshaping data with the reshape package. 2006;1-25.

575 62. Wickham H. The split-apply-combine strategy for data analysis. 2009;1-26.

576 63. Wickham H. Elegant graphics for data analysis. Media 2009;35:211. 
64. McMurdie PJ, Holmes S. Phyloseq: an R package for reproducible interactive analysis and graphics of microbiome census data. PLoS One;8. Epub ahead of print 2013. DOI: 10.1371/journal.pone.0061217.

65. Grömping U. Relative importance for linear regression in R: the package relaimpo. J Stat Softw 2006;17:1-27.

66. Bastian M, Heymann S. Gephi : an open source software for exploring and manipulating networks.

67. Hu Y. Efficient, high-quality force-directed graph drawing. Math J 2006; 10:37-71.

68. Tirol-Padre A, Ladha JK. Assessing the Reliability of Permanganate-Oxidizable Carbon as an Index of Soil Labile Carbon. Soil Sci Soc Am J 2004;68:969-978.

69. Culman SW, Snapp SS, Freeman MA, Schipanski ME, Beniston J, et al. Permanganate Oxidizable Carbon Reflects a Processed Soil Fraction that is Sensitive to Management. Soil Sci Soc Am J 2012;76:494-504.

70. Koechli CN. Land management affects microbial community composition and function in carbon cycling. Cornell University; 2016.

71. Ranea JAG, Grant A, Thornton JM, Orengo CA. Microeconomic principles explain an optimal genome size in bacteria. Trends Genet 2005;21:21-25.

72. Nielsen DA, Fierer N, Geoghegan JL, Gillings MR, Gumerov V, et al. Aerobic bacteria and archaea tend to have larger and more versatile genomes. Oikos 2021;130:501-511.

73. Chen Y, Leung PM, Wood JL, Bay SK, Kessler AJ, et al. Metabolic flexibility allows bacterial habitat generalists to become dominant in a frequently disturbed ecosystem. ISME $J$. Epub ahead of print 2021. DOI: 10.1038/s41396-021-00988-w.

74. Brewer TE, Handley KM, Carini P, Gilbert JA, Fierer N. Genome reduction in an abundant and ubiquitous soil bacterium 'Candidatus Udaeobacter copiosus'. Nat Microbiol;16198. Epub ahead of print 2016. DOI: 10.1038/nmicrobiol.2016.198.

75. Willms IM, Rudolph AY, Göschel I, Bolz SH, Schneider D, et al. Globally Abundant "Candidatus Udaeobacter" Benefits from Release of Antibiotics in Soil and Potentially Performs Trace Gas Scavenging. mSphere 2020;5:1-17.

76. Kaboré OD, Godreuil S, Drancourt M. Planctomycetes as host-associated bacteria: a perspective that holds promise for their future isolations, by mimicking their native environmental niches in clinical microbiology laboratories. Front Cell Infect Microbiol 2020;10:1-19.

77. Morton JT, Marotz C, Washburne A, Silverman J, Zaramela LS, et al. Establishing microbial composition measurement standards with reference frames. Nat Commun. Epub ahead of print 2019. DOI: 10.1038/s41467-019-10656-5.

78. Lin Y, Gifford S, Ducklow H, Shofield O, Cassar N. Towards quantitative microbiome community profiling using internal standards. Appl Environ Microbiolgy 2018;85:e0263418.

79. Smets W, Leff JW, Bradford MA, McCulley RL, Lebeer S, et al. A method for simultaneous measurement of soil bacterial abundances and community composition via 16S rRNA gene sequencing. Soil Biol Biochem 2016;96:145-151.

80. Tkacz A, Hortala M, Poole PS. Absolute quantitation of microbiota abundance in environmental samples. Microbiome 2018;6:1-13. 
81. Tourlousse DM, Yoshiike S, Ohashi A, Matsukura S, Noda N, et al. Synthetic spike-in standards for high-throughput 16S rRNA gene amplicon sequencing. Nucleic Acids Res 2017;45:e23.

82. Zhalnina K, De Quadros PD, Gano KA, Davis-Richardson A, Fagen JR, et al. Ca. Nitrososphaera and Bradyrhizobium are inversely correlated and related to agricultural practices in long-term field experiments. Front Microbiol 2013;4:1-13.

83. Roller BRK, Stoddard SF, Schmidt TM. Exploiting rRNA operon copy number to

84. Schmidt R, Mitchell J, Scow K. Cover cropping and no-till increase diversity and symbiotroph: saprotroph ratios of soil fungal communities. Soil Biol Biochem 2019;129:99-109.

85. Land M, Hauser L, Jun S, Nookaew I, Leuze MR, et al. Insights from 20 years of bacterial genome sequencing. 2015;141-161.

86. Gil R, Latorre A, Postal A. Factors behind junk DNA in bacteria. Genes (Basel) 2012;3:634-650.

87. Westra ER, Van houte S, Oyesiku-Blakemore S, Makin B, Broniewski JM, et al. Parasite exposure drives selective evolution of constitutive versus inducible defense. Curr Biol 2015;25:1043-1049.

88. Williamson KE, Radosevich M, Wommack KE. Abundance and diversity of viruses in six Delaware soils. Appl Environ Microbiol 2005;71:3119-3125.

89. Williamson KE, Corzo KA, Drissi CL, Buckingham JM, Thompson CP, et al. Estimates of viral abundance in soils are strongly influenced by extraction and enumeration methods. Biol Fertil Soils 2013;49:857-869.

90. Westra ER, Van Houte S, Gandon S, Whitaker R, Houte S Van, et al. The ecology and evolution of microbial CRISPR-Cas adaptive immune systems. Philos Trans $R$ Soc B Biol Sci;374. Epub ahead of print 2019. DOI: 10.1098/rstb.2019.0101.

91. Saifuddin M, Bhatnagar JM, Finzi AC, Segrè D, Finzi AC. Microbial carbon use 


\section{Table Legends}

Table 1. An overview of genomic traits used to infer life-history strategies, their corresponding frameworks and the expected relationship between genomic traits and soil health. Genomic traits were derived from a collection of isolate genomes, single cell amplified genomes and metagenome-assembled genomes, assigned to bacterial taxa and used to calculate communityweighted trait averages using relative abundance information. Community-weighted averages were correlated with health ratings to test whether trends in life-history frameworks corresponded with differences in soil health. Biosynthetic gene clusters encode pathways for the production of secondary metabolites commonly involved in antibiosis and resource acquisition, which are associated with a more independent life-history strategy. CRISPR arrays corresponds to the number of arrays in a genome and not the length or number of protospacer adjacent motifs.

Table 2. Comparisons of the variation in (a) community composition and (b) total health score explained by community-weighted traits and environment-wide associations (shaded) according to $\mathrm{R}^{2}$ values from PERMANOVA, in (a), and the relative importance of each variable in linear regression (RELAIMPO) in (b). Community composition was compared based on Bray-Curtis dissimilarity. Each panel contains two separate analyses - one based on the broad categorization of environment-wide associations (upper) and another based on sub-categorization of study factors (see Table S2 for details). 
bioRxiv preprint doi: https://doi.org/10.1101/2022.02 03.479020; this version posted February 3, 2022. The copyright holder for this preprint (which was not certified by peer review) is the author/funder, who has granted bioRxiv a license to display the preprint in perpetuity. It is made available under aCC-BY-NC-ND 4.0 International license.

Table 1.

\begin{tabular}{|c|c|c|c|c|}
\hline Genomic trait & Life-history framework & $\begin{array}{l}\text { Expected } \\
\text { Relationship to Soil } \\
\text { Health }\end{array}$ & Expectation & References \\
\hline Genome size & $\begin{array}{l}\text { Generalist / competitor (large) - } \\
\text { specialist / yield-adapted (small) }\end{array}$ & Positive & $\begin{array}{l}\text { Generalists / competitors will be favored by higher } \\
\text { quality and quantity of OM in healthier soils based on } \\
\text { greater metabolic versatility. }\end{array}$ & $\begin{array}{l}\text { Schmidt et al., } 2018 \\
\text { Malik et al., } 2020\end{array}$ \\
\hline $\begin{array}{l}\text { rrn copy number } \\
\text { (growth rate) }\end{array}$ & Copiotroph (high) - oligotroph (low) & Negative & $\begin{array}{l}\text { Copiotrophs will be favored by management practices } \\
\text { that disturb soil and will correspond with lower health. }\end{array}$ & $\begin{array}{l}\text { Roller et al., 2016; } \\
\text { Westoby et al., 2021; } \\
\text { Schmidt et al., } 2018 \\
\end{array}$ \\
\hline $\begin{array}{l}\text { * Biosynthetic } \\
\text { gene clusters }\end{array}$ & Independent (high) - dependent (low) & Negative & $\begin{array}{l}\text { Independent bacteria will be prevalent in degraded } \\
\text { soils where self-sufficiency provides greater fitness. }\end{array}$ & Wilhelm et al., 2021 \\
\hline Coding density & - & Exploratory & $\begin{array}{l}\text { Low c.d. is common in obligate mutualists, which will } \\
\text { be more abundant in healthier soils where biomass } \\
\text { and cell densities are highest. }\end{array}$ & $\begin{array}{l}\text { McCutcheon et al., 2011; } \\
\text { Gil and Latorre, 2012; } \\
\text { Land et al., } 2015\end{array}$ \\
\hline CRISPR array & - & Exploratory & $\begin{array}{l}\text { Phage abundance is positively correlated with biomass } \\
\text { and organic matter, but the fitness tradeoffs between } \\
\text { CRISPR and other phage defense mechanisms make } \\
\text { this relationship difficult to predict. }\end{array}$ & $\begin{array}{l}\text { Westra et al. 2019; } \\
\text { Williamson et al., 2005; } \\
\text { Williamson et al., 2013; } \\
\text { Liang et al., } 2019\end{array}$ \\
\hline
\end{tabular}

* Biosynthetic gene clusters encode pathways for the production of secondary metabolites commonly involved in antibiosis and resource acquisition 
bioRxiv preprint doi: https://doi org/10.1101/2022 02.03 .479020 . this version posted February 3,2022 . The copyright holder for this preprint (which was not certified by peer review) is the author/funder, who has granted bioRxiv a license to display the preprint in perpetuity. It is made available under aCC-BY-NC-ND 4.0 International license.

Table 2.

\begin{tabular}{|l|l|r|}
\cline { 2 - 3 } & \multicolumn{2}{|l|}{ Variation in Community Composition } \\
\cline { 2 - 3 } & \multicolumn{1}{|c|}{$\begin{array}{c}\text { Community-weighted trait / } \\
\text { environment-wide association }\end{array}$} & \multicolumn{1}{c|}{$\mathrm{R}^{2}$} \\
\hline \multirow{5}{*}{ Category } & 0.045 \\
\cline { 2 - 3 } & Disturbance & 0.039 \\
\cline { 2 - 3 } & Management & 0.035 \\
\cline { 2 - 3 } & Genome size & 0.03 \\
\cline { 2 - 3 } & Plant association & 0.019 \\
\cline { 2 - 3 } & Coding density & 0.017 \\
\cline { 2 - 3 } Sub-category copy number & 0.031 \\
\hline \multirow{5}{*}{} & Organic matter quality & 0.03 \\
\cline { 2 - 3 } & Tillage & 0.03 \\
\cline { 2 - 3 } & Organic vs. conventional & 0.03 \\
\cline { 2 - 3 } & Genome size & 0.022 \\
\cline { 2 - 3 } & Drought & 0.022 \\
\cline { 2 - 3 } & Land use & 0.021 \\
\cline { 2 - 3 } & Host association & 0.017 \\
\cline { 2 - 3 } & Coding density & 0.013 \\
\cline { 2 - 3 } & rrn copy number & \\
\cline { 2 - 3 } & NPK fertilization & \\
\hline
\end{tabular}

\begin{tabular}{|c|c|}
\hline \multicolumn{2}{|l|}{ Variation in Soil Health Score } \\
\hline $\begin{array}{l}\text { Community-weighted trait / } \\
\text { environment-wide association }\end{array}$ & $\begin{array}{l}\text { Rel. } \\
\text { Imp. }\end{array}$ \\
\hline Genome size & 71 \\
\hline Management & 9.7 \\
\hline Coding density & 7.2 \\
\hline rrn copy number & 5.9 \\
\hline Disturbance & 5 \\
\hline Plant association & 1.1 \\
\hline Genome size & 36 \\
\hline Tillage & 20 \\
\hline Organic matter quality & 12 \\
\hline Drought & 9.4 \\
\hline NPK fertilization & 5.9 \\
\hline Coding density & 4.7 \\
\hline$r r n$ copy number & 3.6 \\
\hline Host association & 3.1 \\
\hline Land use & 2.9 \\
\hline Organic vs. conventional & 2.3 \\
\hline
\end{tabular}

Community-weighted trait Environment-wide association 


\section{Figures}

Figure 1. A correlation matrix showing the relationships among soil health ratings, DNA yield and soil texture. Health ratings are grouped by biological (green), physical (yellow), texture (gray), and chemical (pink) classes. The strength of each Pearson's correlation corresponds with the intensity of color of blue $(r>0)$ and red $(r<0)$. The larger the circles the lower the $p$-value with non-significant correlations indicated by a small, colorless circle. Higher hardness ratings correspond with more compaction which explains the negative correlation with total health score. Minor elements and phosphorus ratings had few significant correlations and are not shown here a complete matrix is provided as Figure $\mathrm{S} 1$.

Figure 2. Network diagrams displaying the co-occurrence of indicators among the three classes of health ratings. Networks were divided based on whether indicators exhibited positive ( $a$ and $b$ ) or negative correlations ( $c$ and d) with health ratings to illustrate the broad differences between indicators of biological versus chemical or physical ratings. Nodes represent indicator OTUs aggregated according to their lowest resolved taxonomic rank (scaled by the total number of OTUs), while edges represent co-occurrence of any OTU as an indicator for the same health rating. Edge weights are scaled by the number of co-occurring OTU common between nodes. In (a) and (c), nodes are colored according to health rating class and, in (b) and (d), according to whether a taxon is represented by a described species. In (a) and (c), nodes were colored based on majority rules according to the number of OTUs representing a given health class. Classes were hyphenated when no majority was achieved.

Figure 3. Correlation matrices illustrating the relationships among genomic traits and total health score based on (a) average trait scores weighted by the relative abundance of taxa-specific traits values (i.e., community-weighted data) in the soil health data or (b) the genomic database used to assign trait values to taxa. This side-by-side comparison illustrates that the relationships among traits in community-weighted data partially reflected the existing relationships observed in the genomic data (Mantel statistic $\mathrm{r}=0.64 ; p=0.01$ ). The strength of each Pearson's correlation corresponds with the intensity of color of blue $(\mathrm{r}>0)$ and red $(\mathrm{r}<0)$, and only significant correlations are colored.

Figure 4. A comparison of total health score and community-weighted traits in tilled and untilled soils visualized as box and whisker plots. Significant differences are denoted with asterisk based on t-tests $(* * p<0.01 ; * * * p<0.001)$.

Figure 5. A summary of correlations between (a) soil health ratings and community-weighted traits and (b) a plot of community-weighted genome size versus active carbon content (colored by rating). In (a), all Pearson's $r>|0.3|$ are shaded blue and all significant correlations are shown in bold. In (b), the relationship was not due to biases arising from differences in the proportion of unclassified taxa assigned traits which was not correlated with active carbon rating $(\mathrm{r}=0.06, p=0.1$; see Figure S7).

Figure 6. Environment-wide associations of the most abundant bacterial indicators representing three of the largest or smallest average genome sizes. Each plot shows every OTU identified as an indicator for study factors grouped by (a) plant association (i.e., bulk versus rhizosphere soil), (b) soil disturbance and (c) broad management strategy. In (b) and (c), indicator values were assigned as positive or negative based on whether a factor was a reference (i.e., no till) or treatment (till) with details of designations provided in Table S2. Only OTUs shared among the AgroEcoDB and 
bioRxiv preprint doi: https://doi.org/10.1101/2022.02.03.479020; this version posted February 3, 2022. The copyright holder for this preprint (which was not certified by peer review) is the author/funder, who has granted bioRxiv a license to display the preprint in perpetuity. It is made available under aCC-BY-NC-ND 4.0 International license.

soil health data were included. Collectively, these six taxa account for $14 \%$ of reads in amplicon libraries. 
Figure 1.
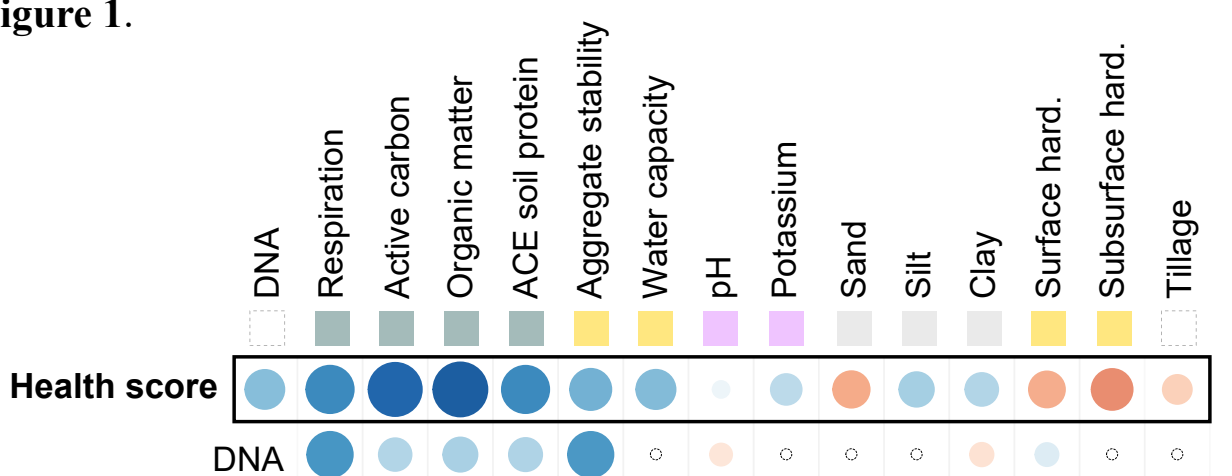

Respiration

Active carbon

Organic matter

ACE soil protein

Aggregate stability

Water capacity

Health Class

\begin{tabular}{|l|l|}
$\square$ & Biological \\
$\square$ & Physical \\
$\square$ & Chemical \\
$\square$ & Texture \\
\hline
\end{tabular}

$\mathrm{pH}$

\section{Potassium}

Sand

Silt

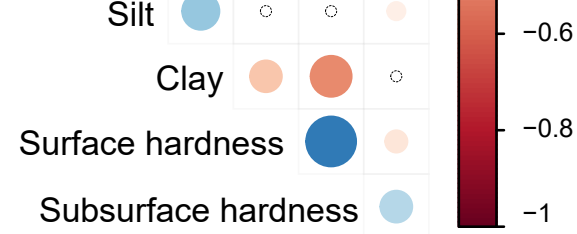


bioRxiv preprint doi: https://doi.org/10.1101/2022.02.03.479020. this version posted February 3,2022 . The copyright holder for this preprint (which was not certified by peer review) is the author/funder, who has granted bioRxiv a license to display the preprint in perpetuity. It is made available under aCC-BY-NC-ND 4.0 International license.

Figure 2.

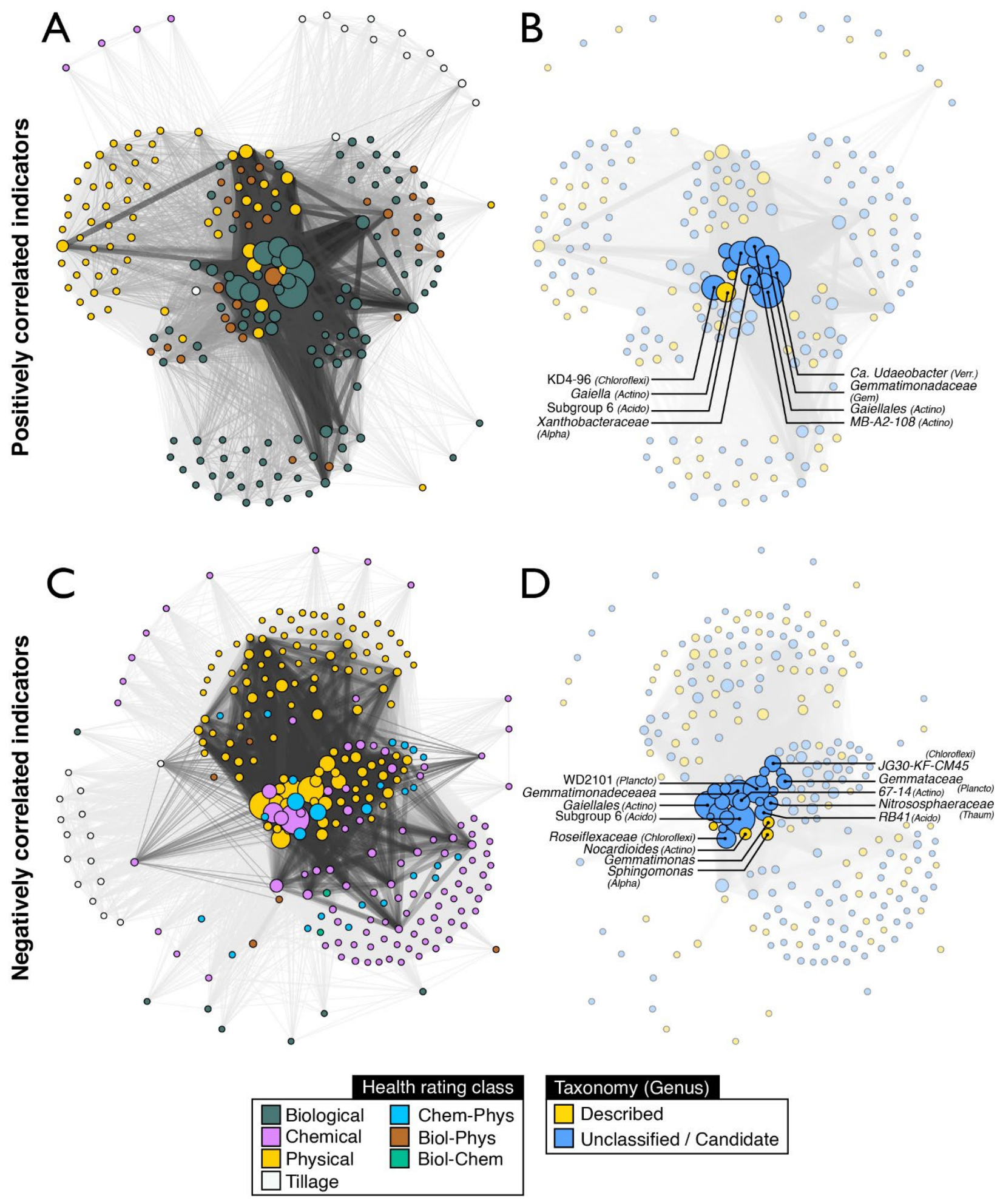




\section{Figure 3.}

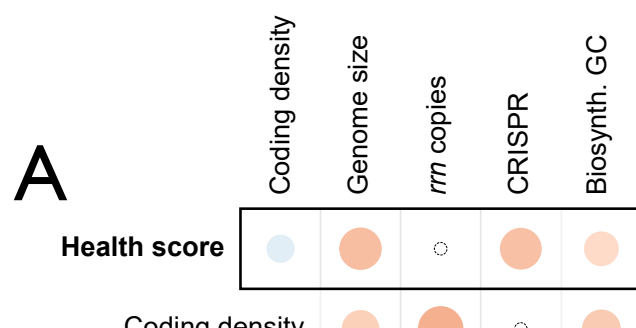

Coding density

Genome size

rrn copies

CRISPR

Community-weighted data

(Soil health dataset)

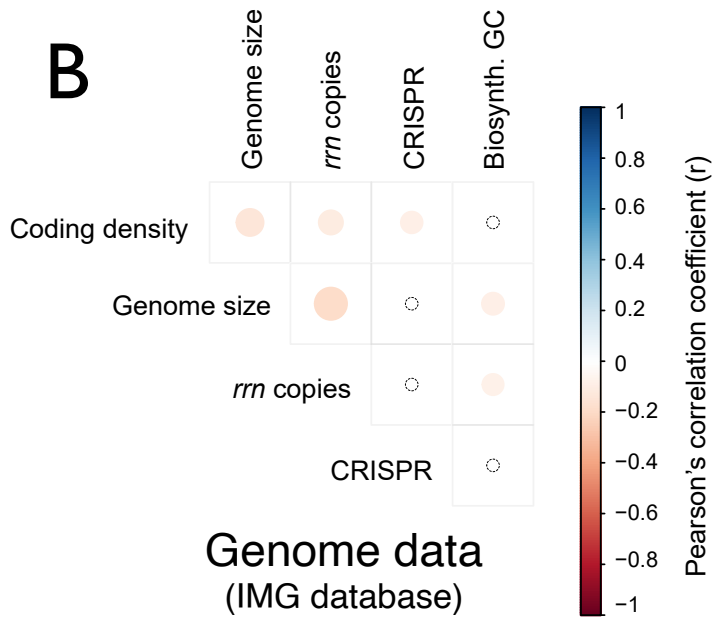




\section{Figure 4.}
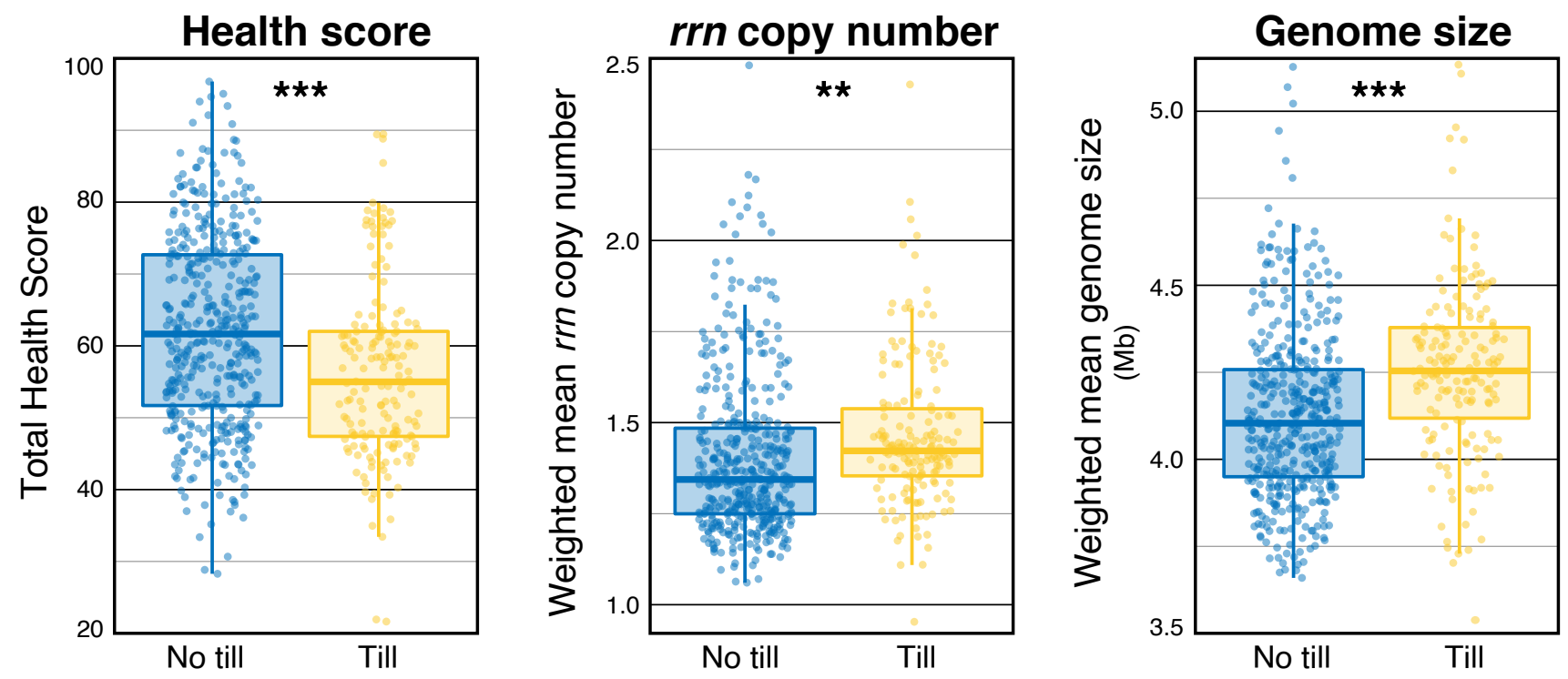
bioRxiv preprint doi: https://doi.org/10.1101/2022.02.03.479020; this version posted February 3, 2022. The copyright holder for this preprint (which was not certified by peer review) is the author/funder, who has granted bioRxiv a license to display the preprint in perpetuity. It is made available under aCC-BY-NC-ND 4.0 International license.

Figure 5.

A
\begin{tabular}{|l|r|r|r|l|l|l|l|l|l|l|l|l|l|l|l|}
\hline $\begin{array}{l}\text { Community- } \\
\text { weighted trait }\end{array}$ & $\begin{array}{l}\text { Health } \\
\text { score }\end{array}$ & DNA & $\begin{array}{l}\text { Active } \\
\text { carbon }\end{array}$ & $\begin{array}{l}\text { ACE } \\
\text { protein }\end{array}$ & $\begin{array}{l}\text { Org. } \\
\text { matter }\end{array}$ & Respir. & $\begin{array}{l}\text { Water } \\
\text { cap. }\end{array}$ & $\begin{array}{l}\text { Agg. } \\
\text { stabil. }\end{array}$ & $\begin{array}{l}\text { Surf. } \\
\text { hard. }\end{array}$ & $\begin{array}{l}\text { Sub. } \\
\text { hard. }\end{array}$ & pH & $\mathrm{P}$ & $\mathrm{K}$ & $\begin{array}{l}\text { Minor } \\
\text { element }\end{array}$ \\
\hline Genome size & -0.306 & -0.108 & -0.444 & -0.302 & -0.218 & -0.195 & -0.016 & -0.141 & -0.172 & -0.006 & -0.222 & 0.062 & 0.091 & -0.29 \\
\hline CRISPR & -0.3 & -0.043 & -0.192 & -0.165 & -0.322 & -0.103 & -0.337 & -0.149 & -0.175 & -0.146 & 0.291 & -0.223 & -0.109 & -0.002 \\
\hline BGCs & -0.199 & -0.079 & -0.31 & -0.316 & -0.165 & -0.078 & -0.034 & -0.003 & -0.02 & -0.001 & -0.128 & -0.035 & 0.121 & -0.098 \\
\hline rrn & 0.003 & -0.066 & 0.001 & -0.026 & 0.034 & -0.011 & 0.096 & -0.146 & -0.316 & -0.316 & 0.118 & -0.153 & 0.078 & 0.04 \\
\hline Coding density & 0.126 & -0.152 & 0.16 & 0.158 & 0.065 & -0.084 & 0.073 & -0.073 & -0.002 & 0.141 & 0.139 & 0.034 & 0.156 & -0.138 \\
\hline
\end{tabular}

B

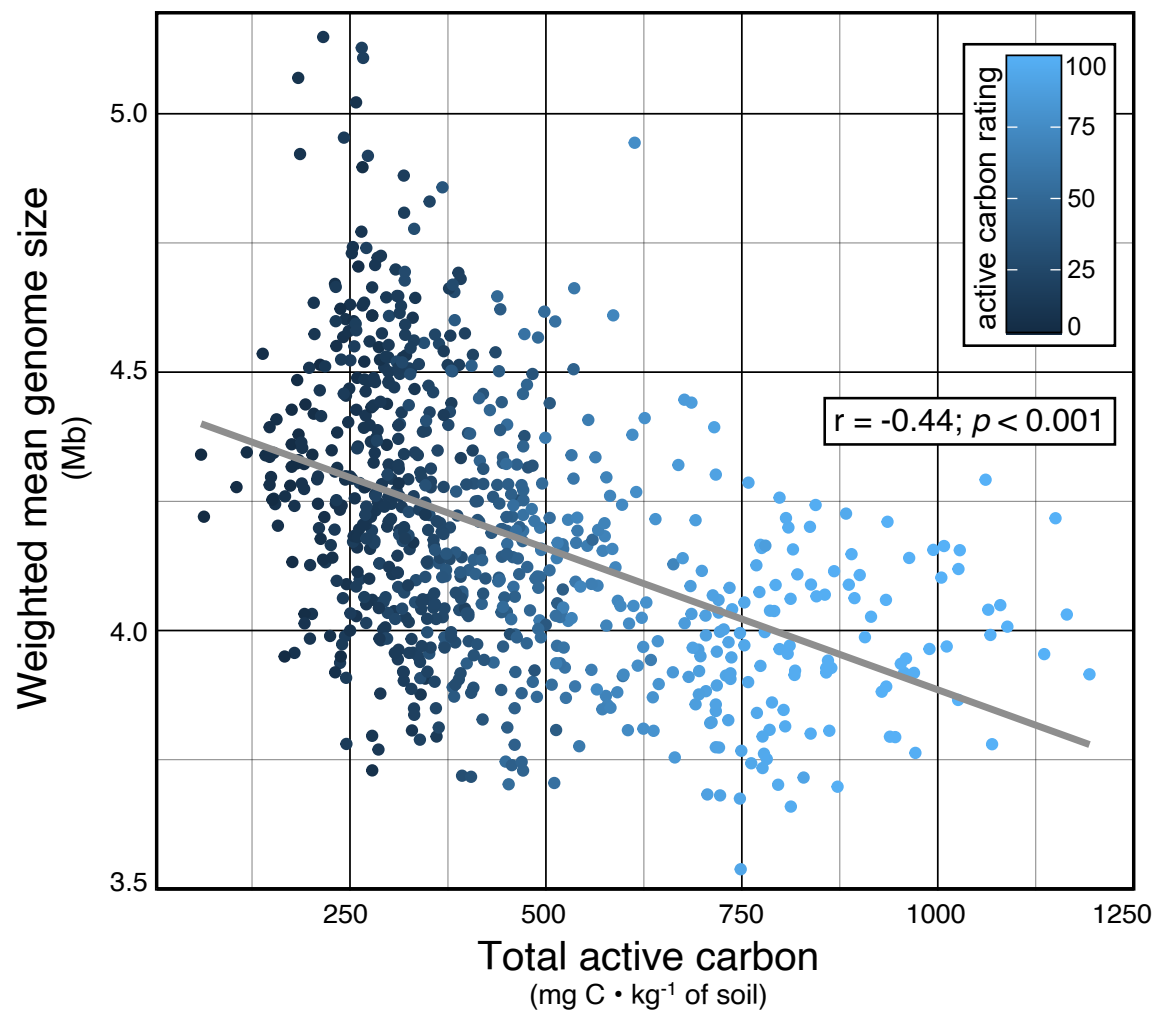




\section{Figure 6.}

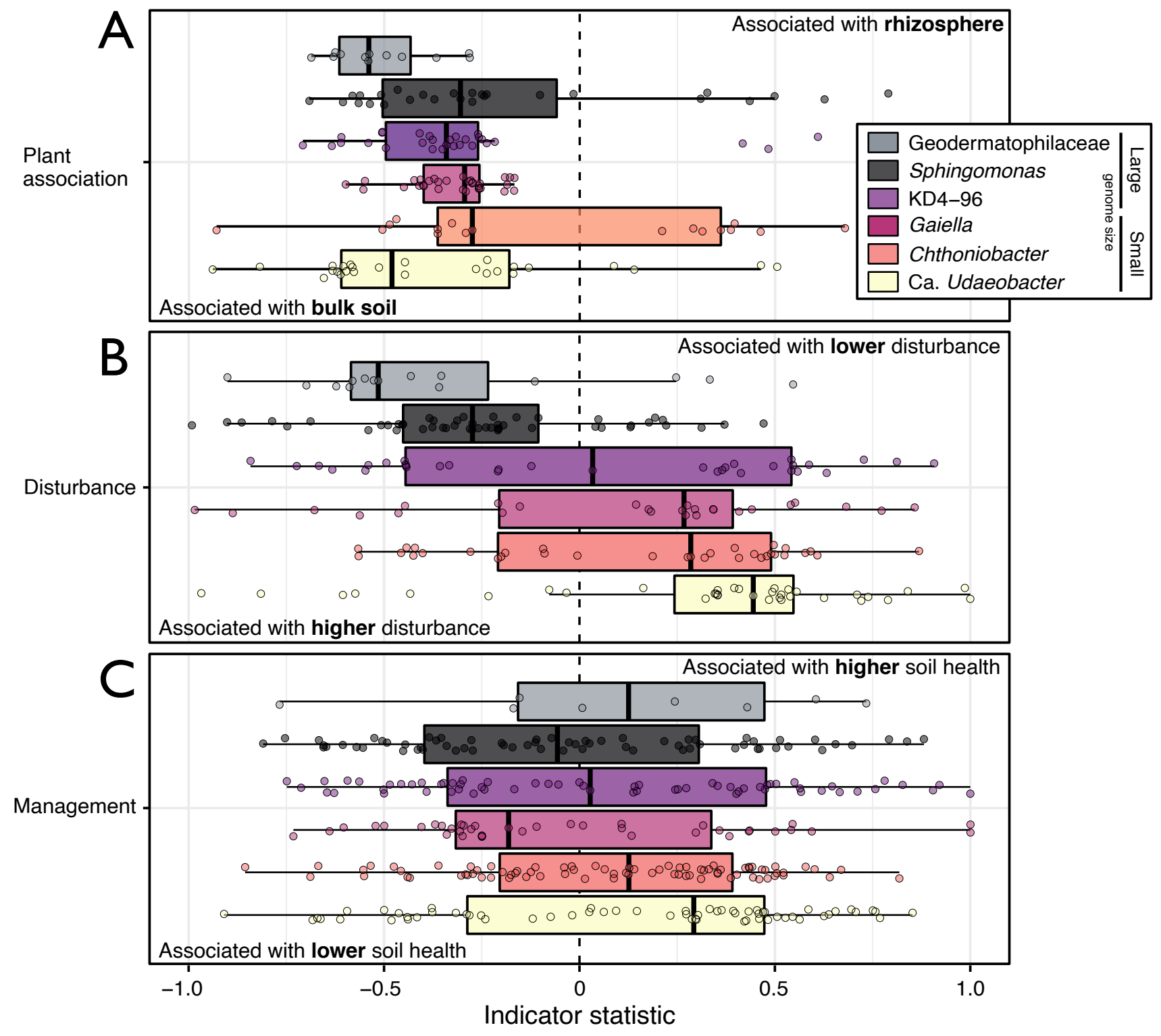


Figure S1. Correlation plot showing pairwise Pearson's r values for all soil health metrics. Non-signifcant correlations are depicted by a hollow circle.

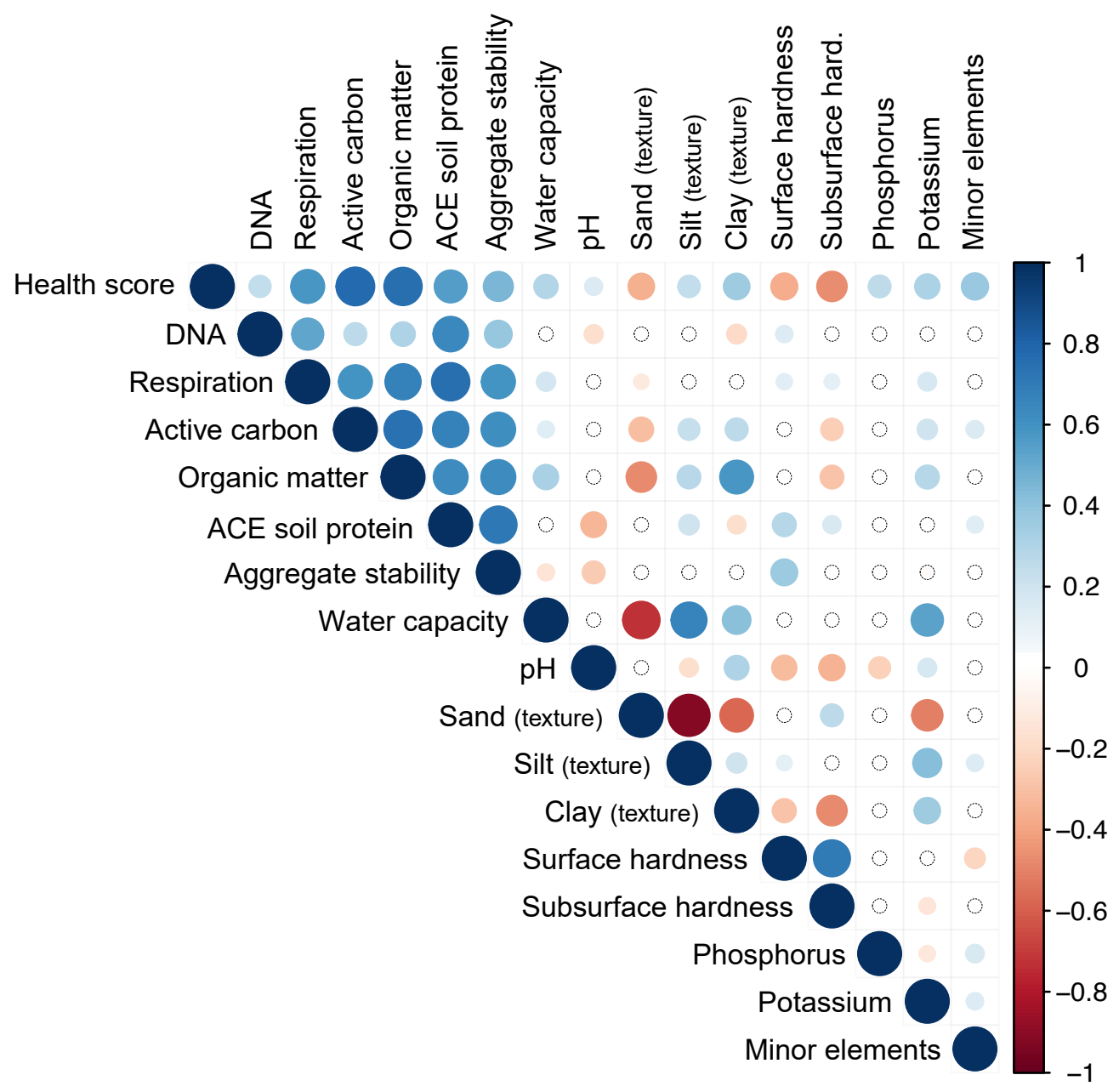



available under aCC-BY-NC-ND 4.0 International license.

Figure S2. The correlation between soil DNA yield and total soil health rating was confounded by high clay content (A) and was improved following the exclusion of soils with $>15 \%$ clay content (B).
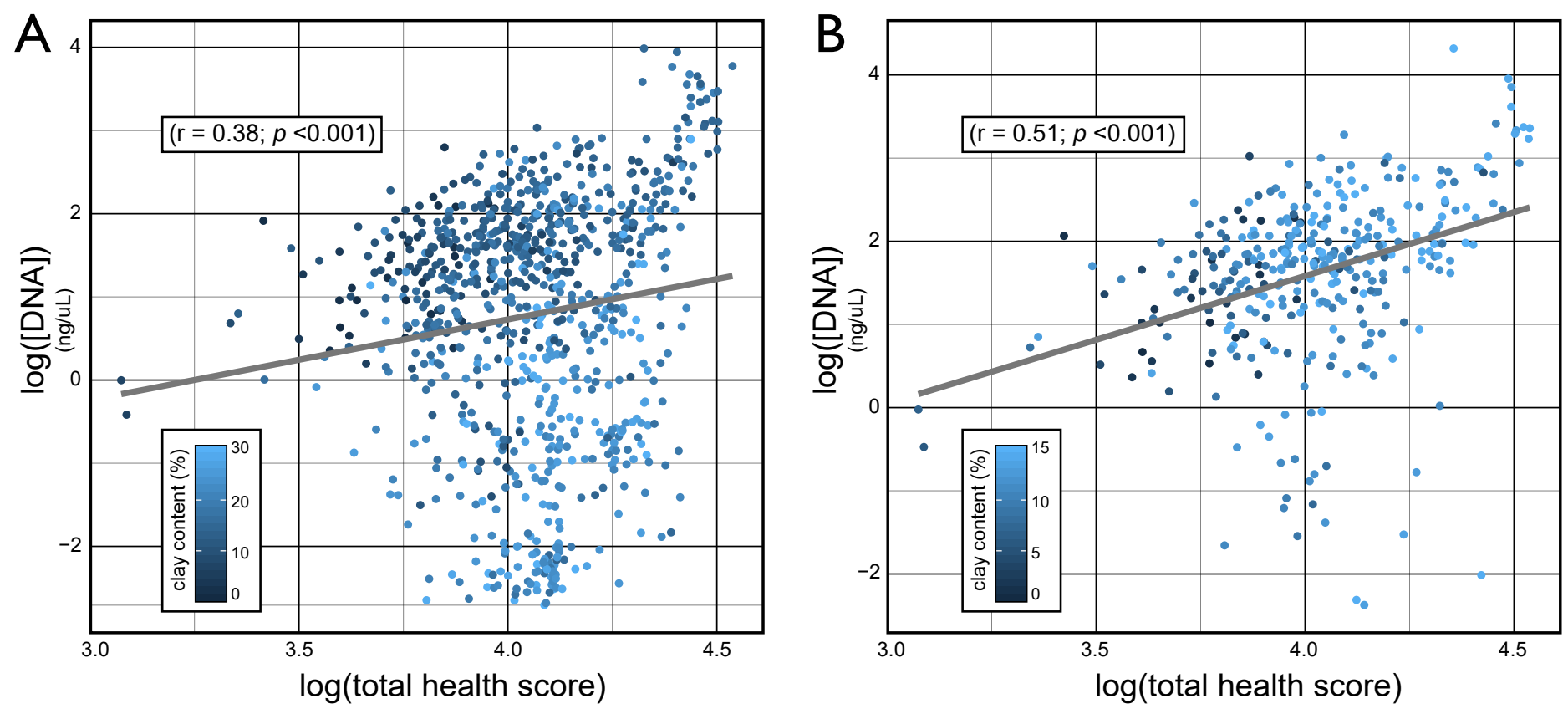
Figure S3. The relative abundance of six bacterial indicator taxa according to active carbon rating and tillage status. On the left, the three indicators with the largest genomes, exhibiting higher relative abundances at lower active carbon ratings and in tilled soils. On the right, the three indicators with the smallest genomes, which exhibited the opposite trends. Collectively, these taxa comprised $14 \%$ of all reads and contributed to trends shown in Figure 4 and Figure 5B. Active carbon ratings were divided into categories based on ranges of 20 , from very low [0 - 20) to very high (80-100]. Pairwise statistically significant differences $(\mathrm{p}<0.05)$, according to Tukey HSD, are denoted by lettering.
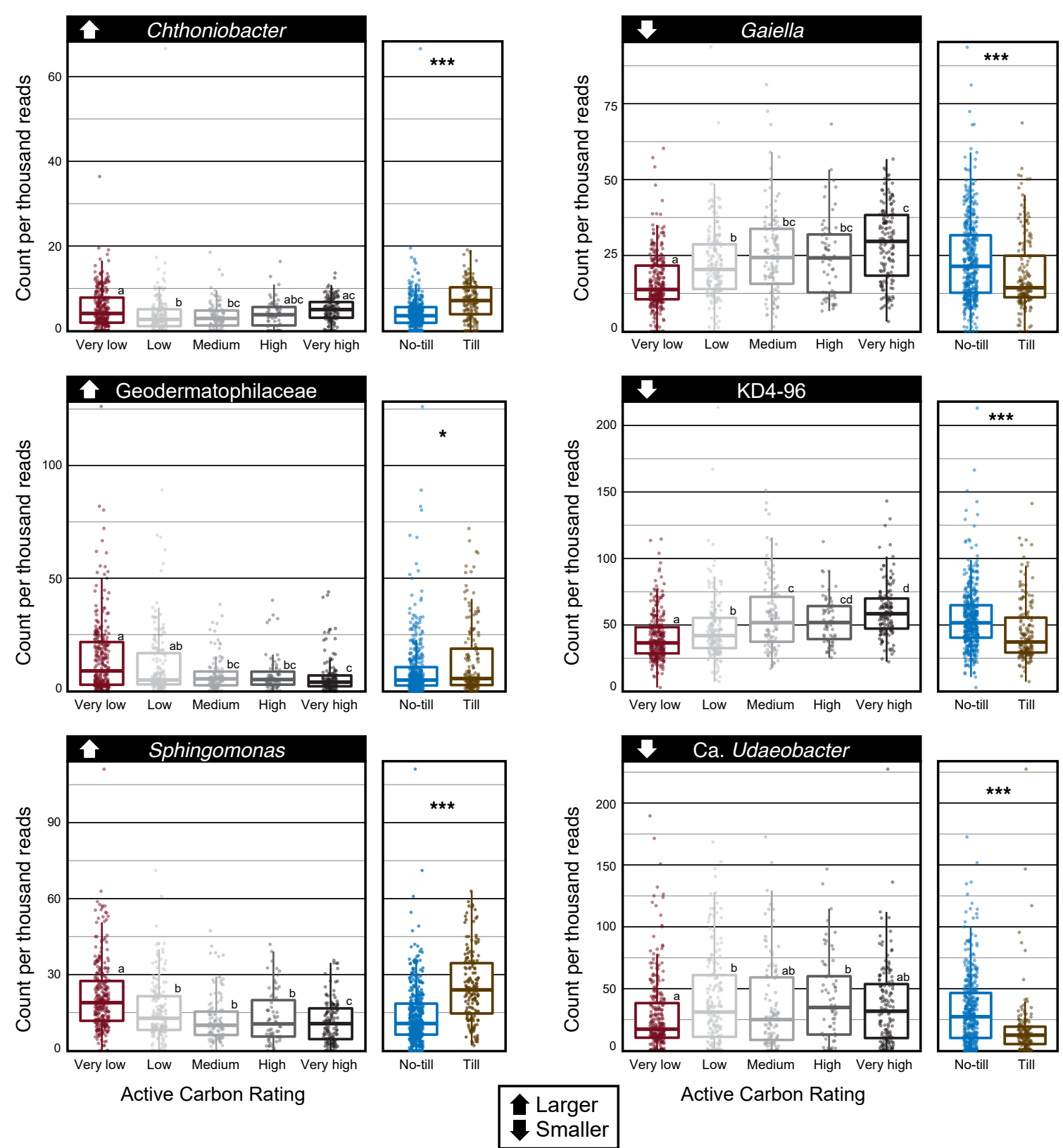

Average genome size 
Figure S4. The association of representative taxa from either end of the spectrum of genome size with tillage status were evident in (A) their environment-wide association in the AgroEcoDB and (B) trends in relative abundance in a study of the long-term effects of tillage and plant residue retention, also present in the AgroEcoDB (Koechli, 2016). Taxa with larger genomes were found at higher relative abundances in tilled fields, while the reverse was true for taxa with smaller genomes, consistent with trends in the soil health data. In (B), statistically supported differences are denoted with lettering based on pairwise Tukey HSD tests $(p<0.05)$.
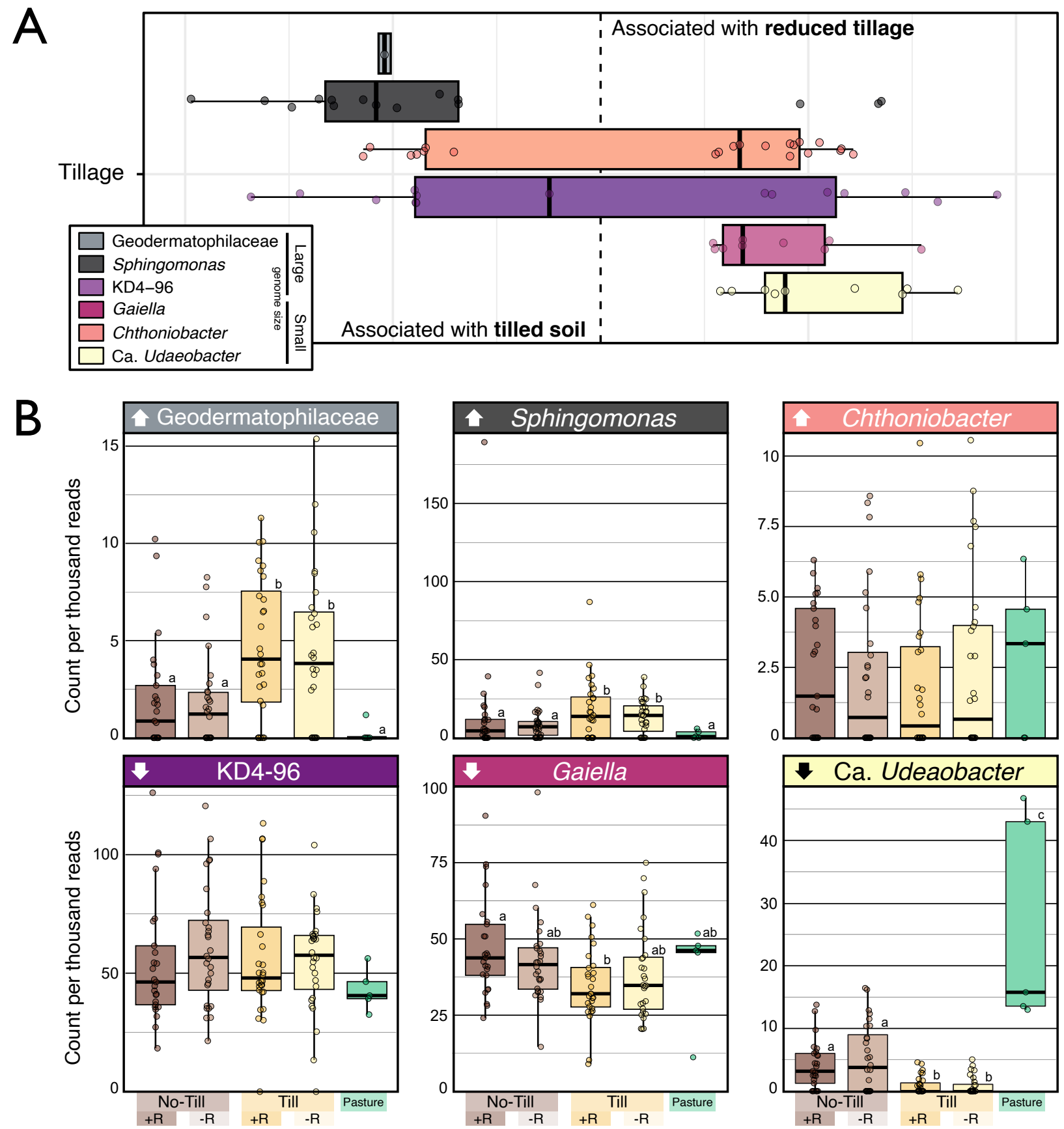

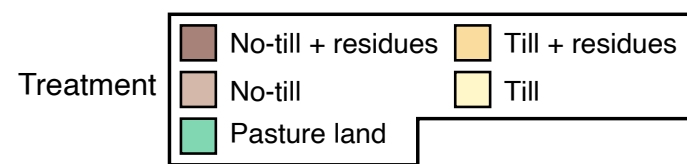


Figure S5. The association of representative taxa from either end of the spectrum of genome size with watering regime was evident in (A) their environment-wide association in the AgroEcoDB and (B) trends in relative abundance in a study of the long-term effects (40 years) of irrigation, also present in the AgroEcoDB (Azarbad et al., 2020). Taxa with smaller genomes were found at higher relative abundance irrigated fields, while the reverse was true for taxa with larger genomes. Statistically supported differences are denoted with lettering based on Wilcoxon tests $(\mathrm{p}<0.05)$.
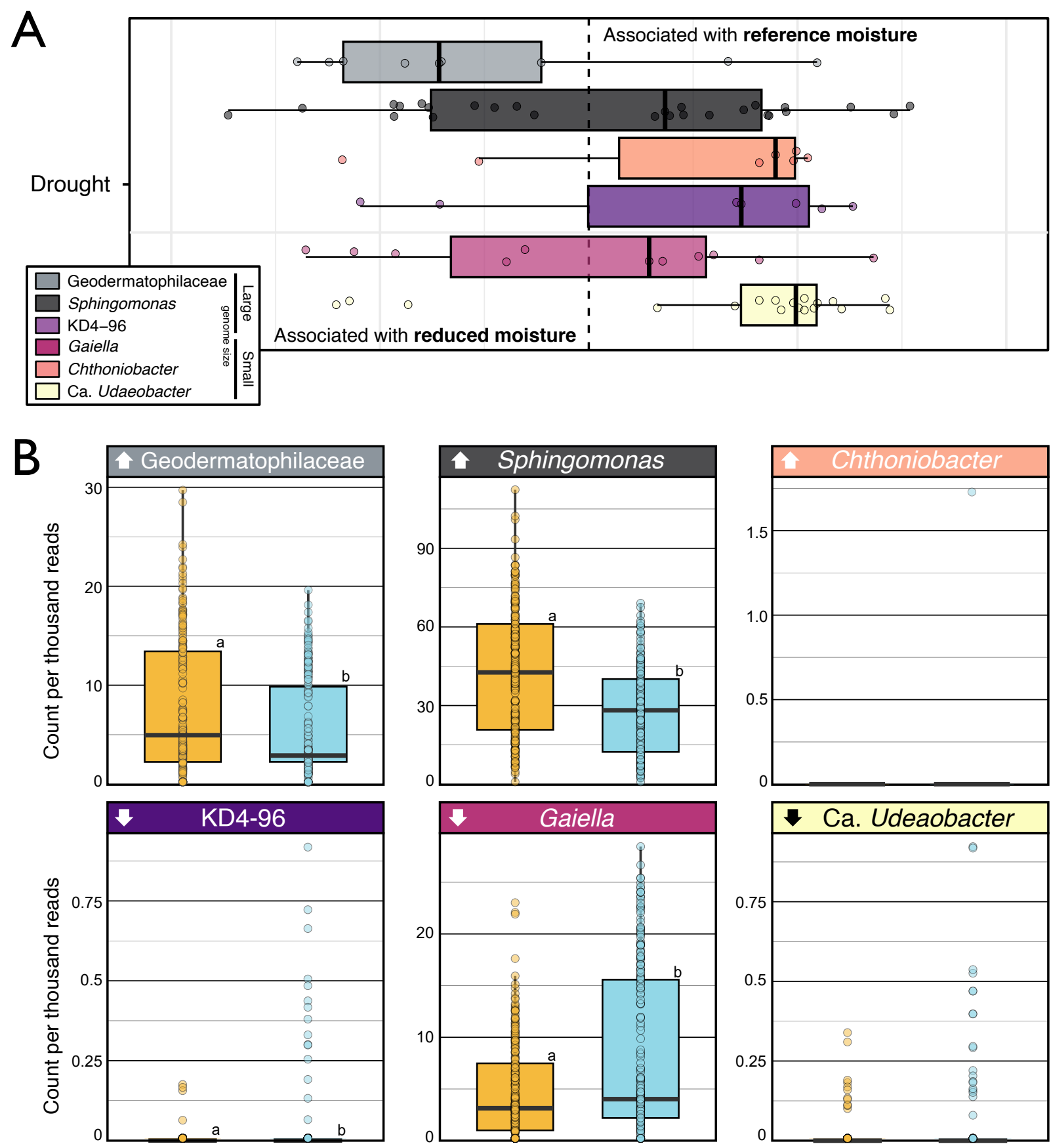

Treatment

No irrigation Irrigation 
bioRxiv preprint doi: https://doi.org/10.1101/2022.02.03.479020; this version posted February 3, 2022. The copyright holder for this preprint (which was not certified by peer review) is the author/funder, who has granted bioRxiv a license to display the preprint in perpetuity. It is made available under aCC-BY-NC-ND 4.0 International license.

Figure S6. Environment-wide associations of Nitrososphaeraceae indicating an association with fertilizer use ('NPK').

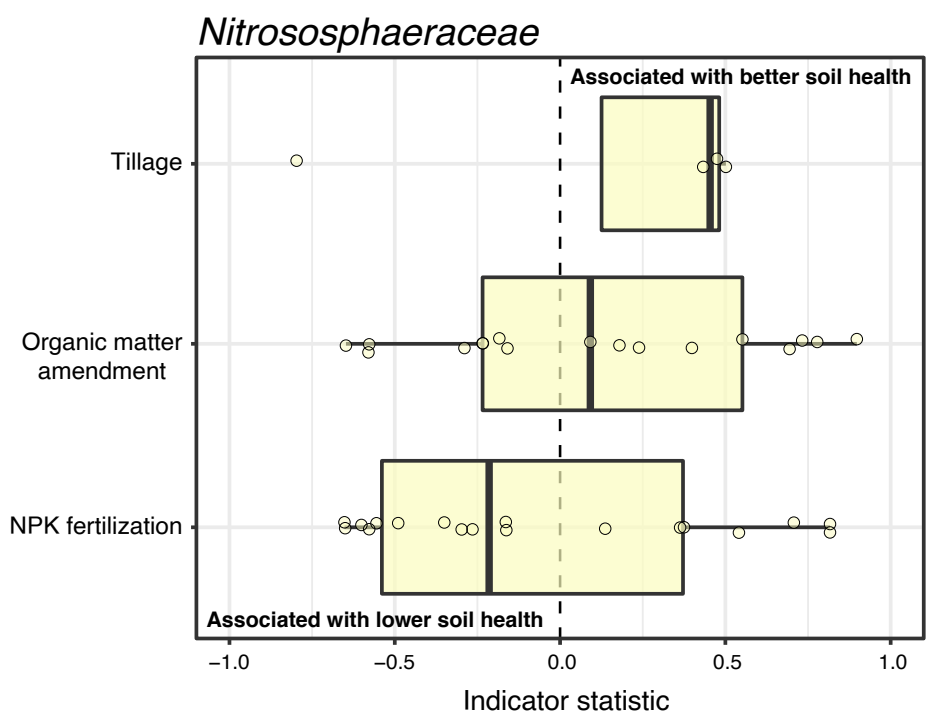


Figure S7. The relative abundance of taxa in amplicon sequencing libraries which could not be assigned a genomic trait. The y-axis corresponds to the aggregate relative abundance of all traitless taxa. There was no correlation with active carbon rating $(r=0.06, p$ $=0.1$ ).

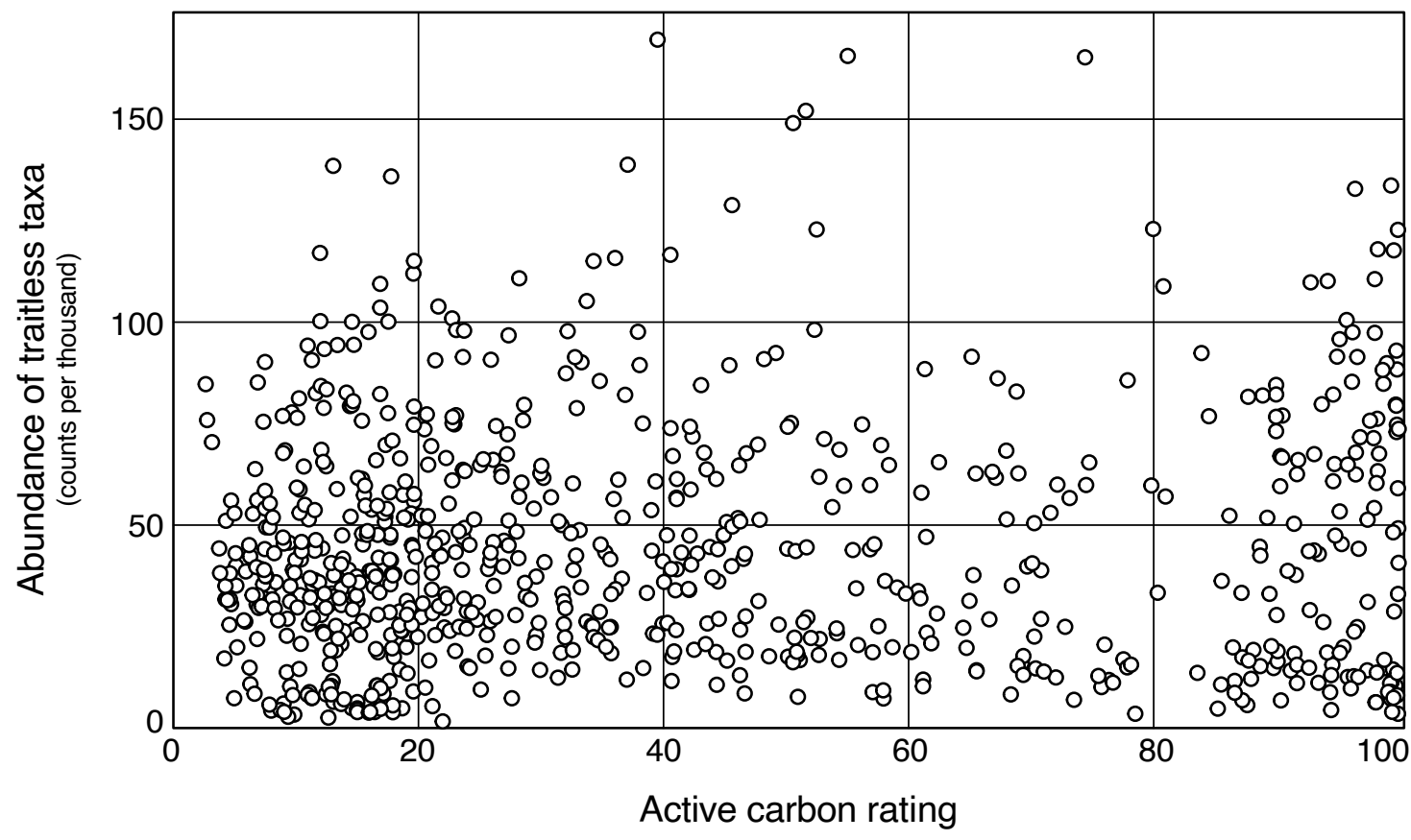




\section{Supplementary Information}

From Wilhelm et al., 2022: "Ecological insights into bacterial indicators of soil health according to their life-history traits and environment-wide associations in agricultural soils."

\section{Downloading Sequencing Projects for the AgroEcoDB}

All amplicon sequencing projects were downloaded using a series of custom scripts available in the Supplementary Data package, which were executed in the following order: (1) 'download.SRA.metagenomes', (2) ‘define.variable.region.py’, (3) ‘download.runs.py’ and (4) 'get.SRA.metadata.py.' In brief, these scripts will (1) download sequencing project information for a set of provided NCBI taxonomy IDs, (2) download a subset of runs $(n=10)$ from each BioProject and determine which variable region of the 16S rRNA gene was targeted using HMMs from VExtractor (Hartmann et al., 2010; included in Supplementary Data) and positional overlap with a reference database, (3) download all sequencing runs from BioProjects which met the criteria (V region etc.) and, finally, (4) download associated study metadata and incorporate into a QIIME2 data object [2]. The identification of overlap with your reference database is critical for ensuring sequences are trimmed to an identical length which is necessary to obtain identical identifiers during ASV calling by DADA2 [3]. In script (3), there is code to 'walk' various starting positions to verify the correct information (optional; but recommended). The trimming parameters used for each sequencing project to match soil health data are provided in Table S2. The initial trimming parameters used in preparing soil health data involved removing $5 \mathrm{nt}$ off of both ends of amplicons produced using the standard 515F / 805R primer pair. Script 3 should be run twice: first with option prep_trim_sheet set to ' $Y$ '. This will output QIIME2 summary 'qzv' which should be used to manually verify the sequencing quality of each project using the website: https://view.qiime2.org/. This will also output a 'trim sheet' that one can use to input trimming parameters for each project (note: trimming may yield sequence data that no longer overlaps with 
the reference project). In creating the AgroEcoDB, the number of reads per library was capped at 50,000 , since keep all the data from larger sequencing project significantly slowed down the process. All phyloseq objects, representative sequences and indicator species output are available in the Supplementary Data package.

These scripts can recreate analyses will likely be of use to readers wishing to expand on the AgroEcoDB or create their own ASV-based database. However, the scripts are hardcoded in many places and do not serve as an out-of-the-box bioinformatic pipeline. There was considerable effort required to standardize metadata for downstream analyses. For example, identifying and consolidating information about the factor codes used in each experiment / sequencing project. This information is available in the Supplementary Data ('agroecoDB - study metadata.xlsx') but be advised that standardizing and cleaning metadata represents the greatest investment in time for building this kind of database. The R script entitled 'BLOCK00 - Refine metadata' is provided in the Supplementary Data which provides an idea of the level of manual intervention required.

\section{References}

1. Hartmann M, Howes CG, Abarenkov K, Mohn WW, Nilsson RH. V-Xtractor : An opensource, high-throughput software tool to identify and extract hypervariable regions of small subunit ( $16 \mathrm{~S} / 18 \mathrm{~S}$ ) ribosomal RNA gene sequences. J Microbiol Methods 2010; 83: $250-253$.

2. Bolyen E, Rideout JR, Dillon MR, Bokulich NA, Abnet CC, Al-Ghalith GA, et al. Reproducible, interactive, scalable and extensible microbiome data science using QIIME 2. Nat Biotechnol 2019; 37: 852-857.

3. Callahan BJ, McMurdie PJ, Rosen MJ, Han AW, Johnson AJA, Holmes SP. DADA2: High-resolution sample inference from Illumina amplicon data. Nat Methods 2016; 13: 581-583. 